\title{
Innovative Household Systems Based on Solid Oxide Fuel Cells for a Northern European climate
}

\author{
Rokni, Masoud; Vialetto, Giulio
}

Published in:

Renewable Energy

Link to article, DOI:

10.1016/j.renene.2015.01.012

Publication date:

2015

Document Version

Peer reviewed version

Link back to DTU Orbit

Citation (APA):

Rokni, M., \& Vialetto, G. (2015). Innovative Household Systems Based on Solid Oxide Fuel Cells for a Northern European climate. Renewable Energy, 78, 146-156. https://doi.org/10.1016/j.renene.2015.01.012

\section{General rights}

Copyright and moral rights for the publications made accessible in the public portal are retained by the authors and/or other copyright owners and it is a condition of accessing publications that users recognise and abide by the legal requirements associated with these rights.

- Users may download and print one copy of any publication from the public portal for the purpose of private study or research.

- You may not further distribute the material or use it for any profit-making activity or commercial gain

- You may freely distribute the URL identifying the publication in the public portal 


\title{
Innovative Household Systems Based on Solid Oxide Fuel Cells for a Northern European climate
}

\author{
Giulio Vialetto and Masoud Rokni \\ Technical University of Denmark, Copenhagen 2800, Denmark \\ MR@mek.dtu.dk
}

\begin{abstract}
Energy saving is an open point in most European countries where energy policies are oriented to reduce the use of fossil fuels, greenhouses emissions and energy independence and to increase the use of renewable energies. In the last several years, new technologies have been developed, and some of them received subsidies to increase installation and reduce cost.

This article presents an innovative cogeneration system based on a solid oxide fuel cell (SOFC) system and heat pump for household applications with a focus on primary energy and economic savings using electric equivalent load parameter which is a function of the electricity and heat demand of the user, and allows different operation strategies to be considered. The proposal is to maximize the efficiency of the system and to make it profitable, even though technologies with a high purchase cost are considered. Simulations of the system are performed under different strategies at a resort located in a northern European climate (Denmark) to cover electricity, space heating and domestic hot water (DHW) demands. The results of these simulations are analyzed with thermodynamic and technoeconomic benchmarks, considering different economic scenarios. The calculations show the high primary energy saving and profitability of the system.
\end{abstract}

Keywords: SOFC; heat pump; operating strategy; hybrid system.

\section{Introduction}

European countries are working to improve their energy policies: one of the themes is energy saving. Publication of the 2010/31 EU Directive is proof of the importance of energy saving in buildings. Insulation and/or more efficient technology (for example, condensing boilers, heat pumps or district heating related to a cogeneration power plant) could help reach these goals. There is currently an increased interest in developing a distributed system of smaller-scale facilities at a single location, allowing electricity and heat to be produced and distributed close to the end user and thereby minimizing the costs associated with transportation [1], [2]. Micro CHP (combined heat and power) for household application falls also within this category. However, micro CHPs face the problem of heat-to power ratio (defined as the ratio between heating demand and electricity consumption) that varies during the day as well as between the seasons due to the different consumption [3].

Solid oxide fuel cells (SOFC) are one of the most promising types of fuel cells, particularly regarding energy production. They are expected to produce clean electrical energy at high convention rates with low noise and low pollutant emissions [4]. SOFC stacks will soon enter the commercialization phase, while heat pumps have been available in the market for decades. It therefore would be interesting to integrate these two technologies into a single system, combining the benefits of each system to establish a new technology.

Numerous studies have been investigated in the literature on SOFC-based hybrid systems that suggest high thermal efficiencies. The majority of these studies use gas turbines as the bottoming cycle for SOFCs (see, e.g., [5], [6], [7]), resulting in pressurized SOFC cycles. 
Steam turbines and organic rankine cycles (ORC) have also been used as a bottoming cycle [8], [9], [10], resulting in non-pressurized SOFC stacks. A few studies have been performed that utilize a Stirling engine as the bottoming cycle and the fuel cell as the topping cycle (see, e.g., [1], [2], [11]). At present, using the Brayton and Rankine cycles as bottoming cycles seems to be the most practical because of the maturity of these technologies. Given that the development trends suggest that the operating temperature of the SOFC will decrease, using a gas turbine as the bottoming cycle will become less beneficial over time. SOFC-steam hybrid systems are more complex but would be interesting systems when an old steam plant is considered for repowering. SOFC-Stirling engine hybrid systems own their benefits from being small scale, starting from 1 to $2 \mathrm{~kW}$.

However, studies on combined SOFC-heat pumps are very rare, e.g., [12] studied the operating conditions and performance of domestic heating systems with heat pumps and SOFCs as micro-cogeneration systems in buildings. The emphasis was to indicate the effect of operating conditions and methodologies rather than the detailed analysis and performance of the units. Other studies in SOFC for residential applications as cogeneration system can be found in e.g. [13] in which the feasibility of a $5 \mathrm{~kW}$ SOFC from economical view was considered. A micro CHP with SOFC for single-family detached dwellings was studied in [14], while the impact of heat-to-power ratio for a SOFC based micro CHP for residential application in European climate was elaborated in [15]. Variation of the heat to power output ratio to match the electric and hot water demands of a Japanese residence can be found in [16].

In this article, an innovative system is proposed, which is mainly based on a solid oxide fuel cell (SOFC) and a heat pump. SOFCs are new technology for power generation, and they are still in the study and design phase. Some of their advantages could be mentioned, including high efficiency, the possibility of cogeneration and a building micro-cogeneration system with a nominal power of 1 to $2 \mathrm{~kW}$. A heat pump, in particular an electric heat pump, is chosen as a backup device to cover the heat demand of the user.

The aim of this study is to not only to present a system suitable for residential applications but also to decrease mismatching between the electricity and heating demand of the user, which is a critical problem in cogeneration systems and particularly in small micro CHP systems. Although the electricity consumption of the user increases when a heat pump is used, heat pumps have considerably higher energy efficiency versus conventional electric heaters, such as electric resistors.

In addition, the aim is also to study the economics of the system presented here by analyzing the thermoeconomy and operating strategy. The operation strategy used here does not follow the electrical or heating demand separately, but considers both together within a single definition. Such investigations are new and have not been considered previously.

\section{Overview of the System}

The main components of the system proposed here are a solid oxide fuel cell (SOFC) plant, heat pump and water tank. The SOFC plant is fed by natural gas for electricity production and for driving the compressor of the heat pump, while its waste heat is recovered for water heating and is used for space heating and domestic hot water (DHW). Fig. 1 displays how they are connected to each other as well as to the grid. The heat pump is used only when the heat available from the SOFC is lower than the heating demand. The water tank stores hot water when the SOFC produces more heat than the user requests. The system is connected to the grid so that when the electricity requirement (from both user and heat pump) exceeds the electricity production from the SOFC, electricity can be drawn from the grid. In the case 
where the request is lower than production, electricity will be supplied to the grid without considering any type of subsidy, such as net metering.

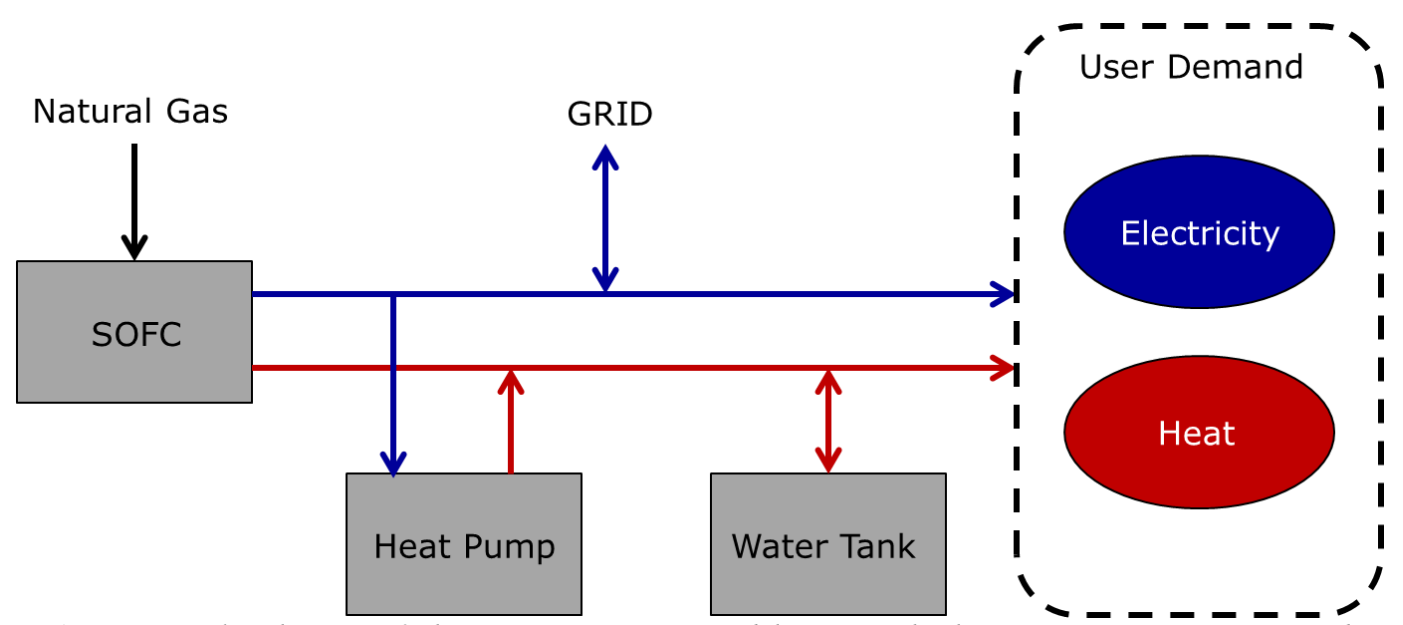

Figure 1. General scheme of the system proposed here with the main component and energy flows: fuel (black), electricity (blue) and heat (red).

\subsection{SOFC}

An SOFC system fuelled by natural gas is simulated using the in-house program DNA. It is made with these components (Fig. 2):

- air compressors to compress the air necessary for the fuel cell system;

- a catalytic partial oxidation (CPO) to convert the heavier hydrocarbons into $\mathrm{CH}_{4}, \mathrm{H}_{2}$ and $\mathrm{CO}$;

- a desulfurizer to remove the sulfur from the fuel and avoid fuel cell poisoning;

- heat exchangers to increase plant efficiency, preheating fuel and air using the off-fuel and off-air, respectively (CP, RP, FP, AP), and to heat water for space heating and domestic hot water (DHW) using the wasted off-gases (HEAT RECOVERY);

- a burner to burn the unused fuel out of the fuel cell;

- SOFC stacks with performances similar to the type developed at DTU Ris $\varnothing$ National Laboratory.

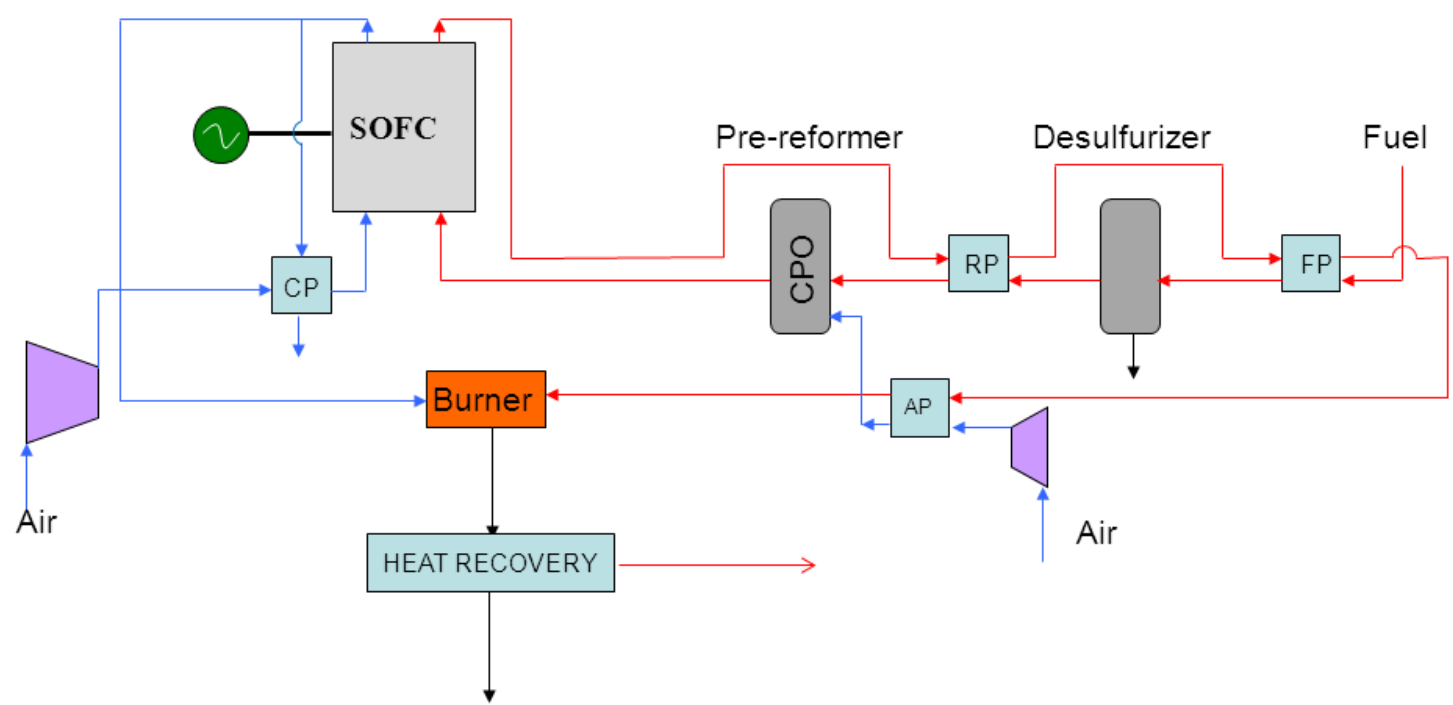

Figure 2. Representation of the $S O F C$ system. $C P=$ cathode preheater, $F P=$ fuel preheater, $A P=$ air preheater, $R P=$ reformer preheater . 
The SOFC system has electricity consumption because of auxiliary components (air compressors) and DC/AC conversion (inverter). Results from the study of [2] show that the electricity consumption for auxiliaries in the SOFC plant is about $1.5 \%$ of the electricity produced by the fuel cell stacks; thus an auxiliary efficiency $\left(\eta_{\text {aux }}\right)$ of $98.5 \%$ is defined. The inverter efficiency $\left(\eta_{\text {inv }}\right)$ is assumed to be $92 \%$, and therefore, the overall transmitted efficiency $\left(\eta_{\text {trans }}\right)$ is defined, considering both auxiliaries and inverter efficiencies as,

$$
\eta_{\text {trans }}=\eta_{\text {aux }} \eta_{\text {inv }}
$$

Under this hypothesis, the $\eta_{\text {trans }}$ can be calculated as 0.9068 .

If $F_{S O F C}$ is the fuel consumption of the SOFC, $H_{S O F C}$ is the heat available for HEAT RECOVERY, and $E_{S O F C}$ is the gross produced electricity (without auxiliary consumption and inverter efficiency), then, the thermal efficiency $\left(\eta_{\text {thermal }}\right)$ and electrical efficiency $\left(\eta_{S O F C}\right)$ of the SOFC plant are defined as,

$$
\begin{aligned}
& \eta_{\text {thermal }, \text { SOFC }}=\frac{H_{S O F C}}{F_{\text {SOFC }}} \\
& \eta_{\text {eletrical,SOFC }}=\frac{E_{\text {SOFC }}}{F_{\text {SOFC }}}
\end{aligned}
$$

Table 1 reports the thermodynamic benchmarks for a simulation of the SOFC system with one stack at full load $(1 \mathrm{~kW})$.

Table 1. Efficiencies of the different components of the system and separate production.

\begin{tabular}{l|c}
\hline \multicolumn{1}{c|}{ Parameter } & Efficiency \\
\hline $\begin{array}{l}\text { SOFC (1 kW, full load), } \\
\text { thermal efficiency }\end{array}$ & $\eta_{\text {thermal,SOFC }}=0.4378$ \\
\hline $\begin{array}{l}\text { SOFC (1 kW, full load), } \\
\text { electrical efficiency }\end{array}$ & $\eta_{\text {electrical }, \text { SOFC }}=0.5299$ \\
\hline $\begin{array}{l}\text { SOFC }(1 \mathrm{~kW}, \text { full load), } \\
\text { heat-to-power ratio }\end{array}$ & $\mathrm{H} / \mathrm{P}=0.8262$ \\
\hline $\begin{array}{l}\text { SOFC auxiliaries consumption, } \\
\text { efficiency on electrical output }\end{array}$ & $\eta_{\text {trans }}=0.9068$ \\
\hline $\begin{array}{l}\text { GSHP, coefficient } \\
\text { performances at W10/W35 }\end{array}$ & $\mathrm{COP}=5.1$ \\
\hline Boiler & $\eta_{\text {boiler }}=0.9$ \\
\hline Electricity (from grid) & $\eta_{e l}=0.439$ \\
\hline
\end{tabular}

\subsection{Heat pump}

If waste heat from the SOFC is not sufficient to cover heat demand, then it is necessary to have a backup component, such as a gas-fired burner or electric heater. However, in this innovative system, a heat pump is chosen to cover heat demand instead of a burner or heater. Usually, two different types of heat pump are available on the market; ground source heat pump (GSHP) and air source heat pump (ASHP). ASHPs are cheaper but in countries where winter days with a temperature just above $0^{\circ} \mathrm{C}$ and a humidity above $50 \%$ are more frequent, 
the possibility of freezing the outdoor section (evaporator) may lead to a decrease in the seasonal performance of the heat pump. Ice has poor heat transfer; therefore, the heat exchange will eventually decrease and then it is necessary to defrost it with, for example, an auxiliary heat source (electrical resistance or gas burner) or by reversing the cycle. A GSHP is chosen for this system because of its higher efficiency, even though it is more expensive. A commercially available GSHP is chosen in this study. To calculate the coefficient of performance (COP) of this heat pump, it was necessary to consider that the working condition differs from the nominal condition. The technical norms of the heat pump used here are:

- UNI-TS 11300-4 to consider different working temperatures at the condenser/evaporator [17];

- EN 14825 to consider the partial load of the heat pump in heating mode based on [18]. In this study, a calculation method based on the model of [19] is developed to consider the UNI-TS 11300-4 standard. The maximum coefficient of performance ( $\left.\mathrm{COP}_{\max }\right)$ of the GSHP is related to the heat sink temperature $\left(\mathrm{T}_{\mathrm{w}, \text { out }}\right)$ and the heat source temperature $\left(\mathrm{T}_{\mathrm{grd}}\right)$ :

$$
C O P_{\max }=\frac{T_{w, \text { out }}+273.15}{T_{w, \text { out }}-T_{\text {grd }}}
$$

The performances of real GSHP systems are always lower than theoretical $\mathrm{COP}_{\max }$, and an exergy efficiency is defined between $\mathrm{COP}_{\max }$ and $\mathrm{COP}$, where COP is given in the technical data sheet of the heat pump producer,

$$
\eta_{e x}=\frac{C O P}{C O P_{\max }}
$$

Generally, heat pump performances are highly sensitive to the operating conditions (heat sink and heat source temperatures and partial load conditions). Following the study of [19] and the method proposed in UNI-TS 11300-4, it is possible to calculate the exergy efficiency of the heat pump if both the nominal performances $\left(\mathrm{COP}_{n o m}\right)$ and nominal temperatures $\left(\mathrm{T}_{\mathrm{w}}\right.$,

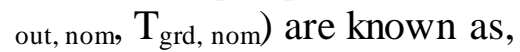

$$
\eta_{\text {ex }, \text { nom }}=\frac{C O P_{\text {nom }}}{C O P_{\text {max }, \text { nom }}}=C O P_{n o m}\left(\frac{T_{w, \text { out }, \text { om }}-T_{\text {grd }, \text { om }}}{T_{w, \text { out }, \text { nom }}+273.15}\right)
$$

The exergy efficiency calculated under nominal conditions is supposed to be constant; therefore, it would be possible to define the GHSP performances (COP, $\mathrm{Q}_{\mathrm{GHSP}}$ ) at different temperatures conditions,

$$
\begin{aligned}
C O P & =\left(\frac{T_{w, \text { out }}+273.15}{T_{w, \text { out }}-T_{\text {grd }}}\right) \eta_{\text {ex, nom }} \\
Q_{G S H P} & =Q_{G S H P, \text { nom }}\left(\frac{T_{w, \text { out }}-T_{\text {grd }, \text { nom }}}{T_{w, \text { out }}-T_{\text {grd }}}\right)
\end{aligned}
$$

To calculate the partial load, the EN 14825 calculation method is also used in this study. The COP at partial load ( $\left.\mathrm{COP}_{\mathrm{PL}}\right)$ is thus defined as,

$$
C O P_{P L}=C O P[1-C d(1-C R)]
$$

where COP is the performance at full load at the same temperature conditions. $C d$ is the degradation factor of the heat pump, and $C R$ that is the capacity ratio. If the degradation factor is unknown or undetermined, EN 14825 suggests the value of 0.25 . The capacity ratio is 
defined as the ratio between the load required ( $\left.\mathrm{Q}_{\mathrm{GSHP}, \text { req }}\right)$ and maximum heating power of the heat pump (Q $\left.\mathrm{Q}_{\mathrm{GSHP}}\right)$ at temperature conditions defined by,

$$
C R=\frac{Q_{G S H P, r e q}}{Q_{G S H P}}
$$

For the proposed system, a commercial heat pump is chosen with a COP of 5.1 at W10/W35 conditions (according to EN 14511) and because $C d$ is unknown, it is assumed to be 0.25 according to EN 14825 . To simulate a GSHP, it is necessary to know the temperature of the water coming from the ground out of the heat exchangers. In this case, it is assumed to be $9{ }^{\circ} \mathrm{C}$ and constant during the year.

\subsection{Water tank}

A water tank is used to store the waste heat from the SOFC when its heat production is higher than the demand for space heating and/or DHW. The temperature range of the water tank will be between $45{ }^{\circ} \mathrm{C}$ to $95{ }^{\circ} \mathrm{C}$ for which the lower limit is the lowest hot water temperature set by the user and the higher temperature limit is to avoid vapor formation. For the very rare case when the temperature of the water tank is at upper limit of $95{ }^{\circ} \mathrm{C}$ and the waste heat from the SOFC is still available, it is proposed that there is a security system to dissipate the heat. For simplification, there is only one water tank to store the heat for both space heating and DHW. Different criteria could be used to choose the heat capacity of the water tank; however in this study, the heat capacity is assumed to be sufficient to keep heat dissipation below $1 \%$ of the total heat production.

\section{Data Collection}

To simulate the energy consumption for a normal house in Denmark, data from the domestic hot water and electrical energy profile must be collected. Data for electricity consumption are taken from a study of heat and power cogeneration [20], which provides the annual consumption of a resort located in the northern countries of Europe, and also the data are logged and stored hourly. Data for the space heating demand is taken from reference [21] in which it is assumed that the useful surface of the house is approximately $150 \mathrm{~m}^{2}$ and is located in the Copenhagen area. Fig. 3 shows the hourly annual demand for space heating, DHW and electricity. The annual total energy demand for space heating is $10,725 \mathrm{kWh}$, for DHW is $2970 \mathrm{kWh}$ and for electricity is $3028 \mathrm{kWh}$. It shall be mentioned that these data are the average values and may change from household to household depending on the habits and living styles of the tenants. 


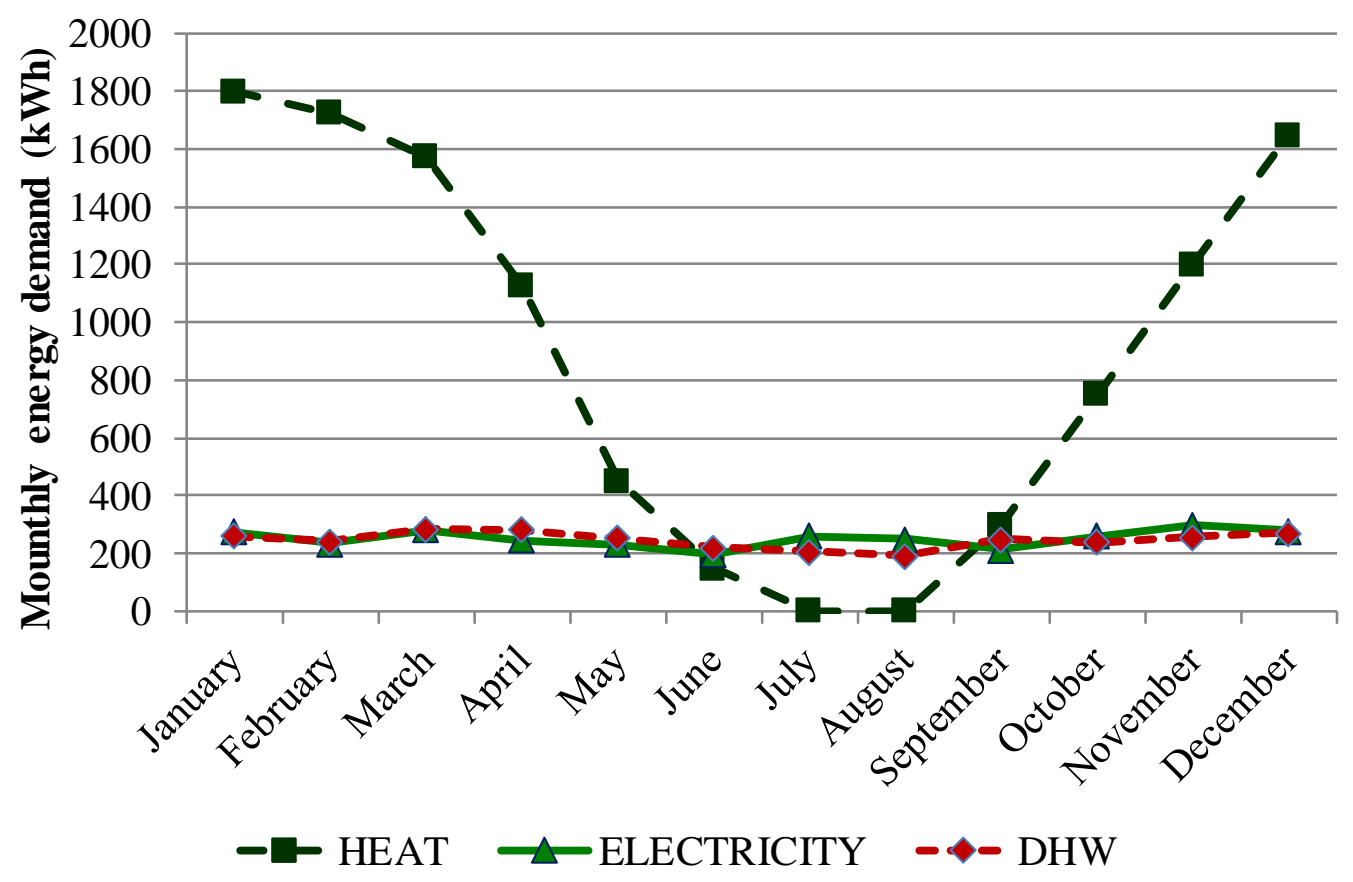

Figure 3. Average monthly demand on electricity, heat and domestic hot water (DHW) for a resort located in Denmark.

\section{Operation Strategy}

The operation strategy is an important part of the system designed and proposed here. Thermodynamic and economical performances are strictly related to the operation strategy in cogeneration and trigeneration systems [22]. An innovative operation strategy defined and analyzed in [22] is also used here, which does not follow electricity or heat demand separately, but considers both of them together and simultaneously. In this strategy, an electric equivalent load (EEL) parameter is defined, which is the electrical demand for both the user and the heat pump. It considers that user heat demand is covered partly by the waste heat of the SOFC and partly by the heat pump. This parameter is thus a function of:

- electrical $\left(E_{U S E R}\right)$ and heating $\left(H_{U S E R}\right)$ user demand;

- heat-to-power ratio $(\mathrm{H} / \mathrm{P})$ and auxiliaries consumption $\left(\eta_{\text {trans }}\right)$ of the SOFC;

- heat pump efficiency (COP).

To define the EEL, some assumptions are made to simplify the calculation method. The electrical consumption of the user ( $\mathrm{E}_{\mathrm{USER}}$ ) and electricity consumption of the GSHP ( $\left.\mathrm{E}_{\mathrm{GSHP}}\right)$ are assumed to be covered only by the electricity produced from the SOFC (E) as,

$$
E_{U S E R}+E_{G S H P}=E
$$

The heating demand ( $\left.\mathrm{H}_{\mathrm{USER}}\right)$ is assumed to be covered by both the GSHP $\left(\mathrm{H}_{\mathrm{GSHP}}\right)$ and waste heat of the SOFC $\left(\mathrm{H}_{\mathrm{SOFC}}\right)$ as,

$$
H_{\text {USER }}=H_{\text {GSHP }}+H_{\text {SOFC }}
$$

It is thus necessary to consider the efficiencies of both the SOFC and GSHP systems. Taking into account the consumption of the auxiliaries of the SOFC, the electricity of the SOFC can thus be found as,

$$
E=\eta_{\text {trans }} E_{\text {SOFC }}
$$


By relating the electricity and heat $\left(\mathrm{H}_{\mathrm{SOFC}}\right)$ production of the $\mathrm{SOFC}$ using the parameter heat-to-power ratio $(H / P)$,

$$
H_{S O F C}=E_{S O F C} \frac{H}{P}
$$

The Heat production of the GSHP $\left(\mathrm{H}_{\mathrm{GSHP}}\right)$ is related to the electricity consumption with the coefficient of performances (COP) through,

$$
H_{G S H P}=E_{G S H P} C O P
$$

The above equations define the EEL under different conditions. If the waste heat from the SOFC is sufficient to cover the heat demand of the user, then the EEL can be defined as

$$
E E L=\frac{E_{U S E R}}{\eta_{\text {trans }}}
$$

However, if the waste heat of the SOFC is not sufficient to cover the heat demand of the user, then it is defined as

$$
E E L=\frac{1}{\eta_{\text {trans }}} \times \frac{E_{U S E R}+\frac{H_{U S E R}}{C O P}}{1+\frac{H / P}{C O P^{*} \eta_{\text {trans }}}}
$$

After defining the EEL parameter, different operation strategies can be used:

- continuous operation $(\mathrm{CO})$, where the produced electricity is constant during a period;

- equivalent electric load following (ELF), where the produced electricity will be equal to the EEL.

Under the CO strategy, the SOFC works at constant power every hour of the day. It is necessary to define which power fuel cell has to work because electricity, heating and DHW demands change hour by hour. Similarly, heating demand changes month by month. This criterion is used for each month to calculate an average value for the EEL. The advantage of this strategy is that the SOFC produces the same amount of electricity constantly for a period of time (for many hours); therefore, the thermal stresses on the cells are eluded. The disadvantage is that a larger water tank is needed to store the heat when water is produced but not consumed. Moreover, the possibility of net metering will then be required to exchange electricity with the net because of mismatching between the electricity production and consumption.

The aim of the ELF operation strategy is to follow the EEL and to cover all of the energy requests of the entire system. The advantage would be that the energy requirement from the grid is only a few times. The disadvantage would be that the fuel cell has to change the electricity production during operation time, and consequently, the thermal stresses on the cells would be higher than the CO strategy. The EEL is not constant during the day, and heating and especially DHW demands have peak hours during the day. If it is chosen to follow the EEL, then it necessary to cover the peaks, which in turn, requires a SOFC with a higher maximum power. However, using a more powerful SOFC (additional stacks) implicates higher cost and longer payback time.

Three different cases are analyzed here: the $\mathrm{CO}$ strategy with a 1-kW maximum electrical power, ELF with a 1-kW maximum power of the SOFC and ELF with $2 \mathrm{~kW}$. Figs. 4 through 
6 show the hourly EEL for ELF $2 \mathrm{~kW}$, ELF $1 \mathrm{~kW}$ and CO, respectively. Each figure represents the electric equivalent load (EEL) and how the corresponding strategy covers it.

The ELF 2-kW (Fig. 4) operation strategy follows the EEL until the demand is lower than the maximum SOFC power, which is $2 \mathrm{~kW}$. If the EEL is higher, then the SOFC works at 2 $\mathrm{kW}$, and the difference between EEL and SOFC electrical production is covered with the grid. Under this strategy, the system is able to cover $96.3 \%$ of the total EEL demand. The ELF 1 $\mathrm{kW}$ (Fig. 5) is similar to ELF $2 \mathrm{~kW}$ but with a smaller nominal SOFC power that is $1 \mathrm{~kW}$ instead. It follows the EEL until $1 \mathrm{~kW}$ but when EEL is higher than $1 \mathrm{KW}$, the SOFC works at $1 \mathrm{~kW}$. Because of a lower nominal power, ELF $1 \mathrm{~kW}$ covers $77.1 \%$ of the EEL demand. The CO (Fig. 6) strategy does not follow the EEL because the SOFC works continuously at a set power. The set point is the monthly average of the EEL. If the average is higher than $1 \mathrm{~kW}$ (maximum power of the SOFC), then the SOFC works at $1 \mathrm{~kW}$.

The size of each component of the system is related to the operation strategy. ELF $1 \mathrm{~kW}$ has a smaller SOFC size than ELF $2 \mathrm{~kW}(1 \mathrm{~kW}$ and $2 \mathrm{~kW}$, respectively); therefore, in the first case, it is necessary to have a larger heat pump for covering the heat demand. The size of the fuel cell, heat pump and water tank for different operation strategies is shown in Table 2. The size of the heat pump for ELF $2 \mathrm{~kW}$ is approximately $11 \%$ smaller than the heat pump for the other two strategies (ELF $1 \mathrm{~kW}$ and CO $1 \mathrm{~kW}$ ), while the size of the water tank for the CO 1$\mathrm{kW}$ strategy must be approximately $43 \%$ larger than the other two ELF strategies.

Table 2. Size of the system components with different operation strategies.

\begin{tabular}{|c|c|c|c|}
\cline { 2 - 4 } \multicolumn{1}{c|}{} & ELF 2 kW & ELF 1 kW & ELF CO \\
\hline SOFC & $2 \mathrm{~kW}$ & $1 \mathrm{~kW}$ & $1 \mathrm{~kW}$ \\
\hline GSHP & $8 \mathrm{~kW}$ & $9 \mathrm{~kW}$ & $9 \mathrm{~kW}$ \\
\hline Water tank & 701 & 701 & 1001 \\
\hline
\end{tabular}

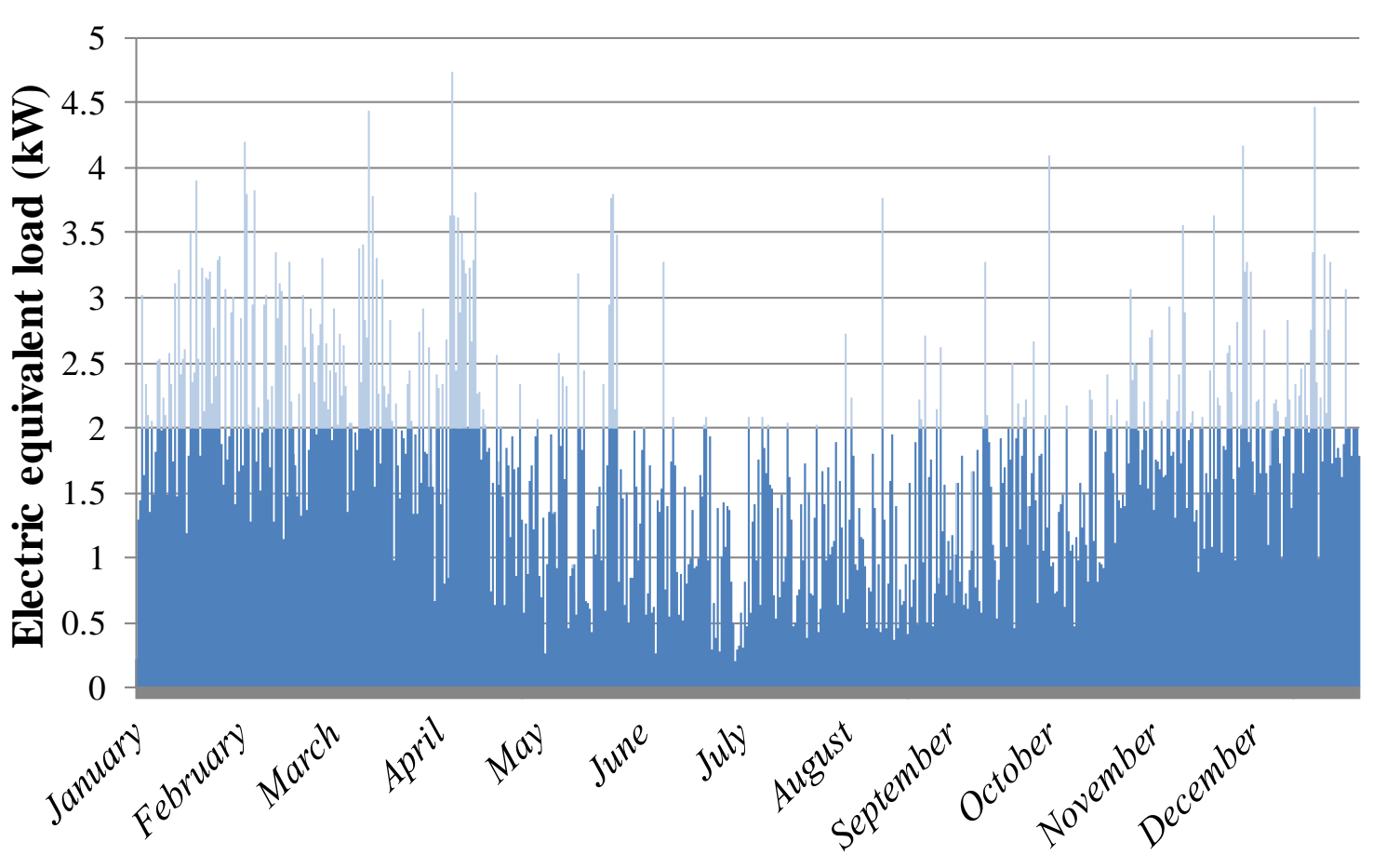

$\square$ EEL $\square$ ELF $2 \mathrm{~kW}$ 
Figure 4. Electric equivalent load with ELF $2 \mathrm{~kW}$, annual overview. ELF $2 \mathrm{~kW}$ follows EEL until it is lower or equal to $2 \mathrm{~kW}$ (the darker color).

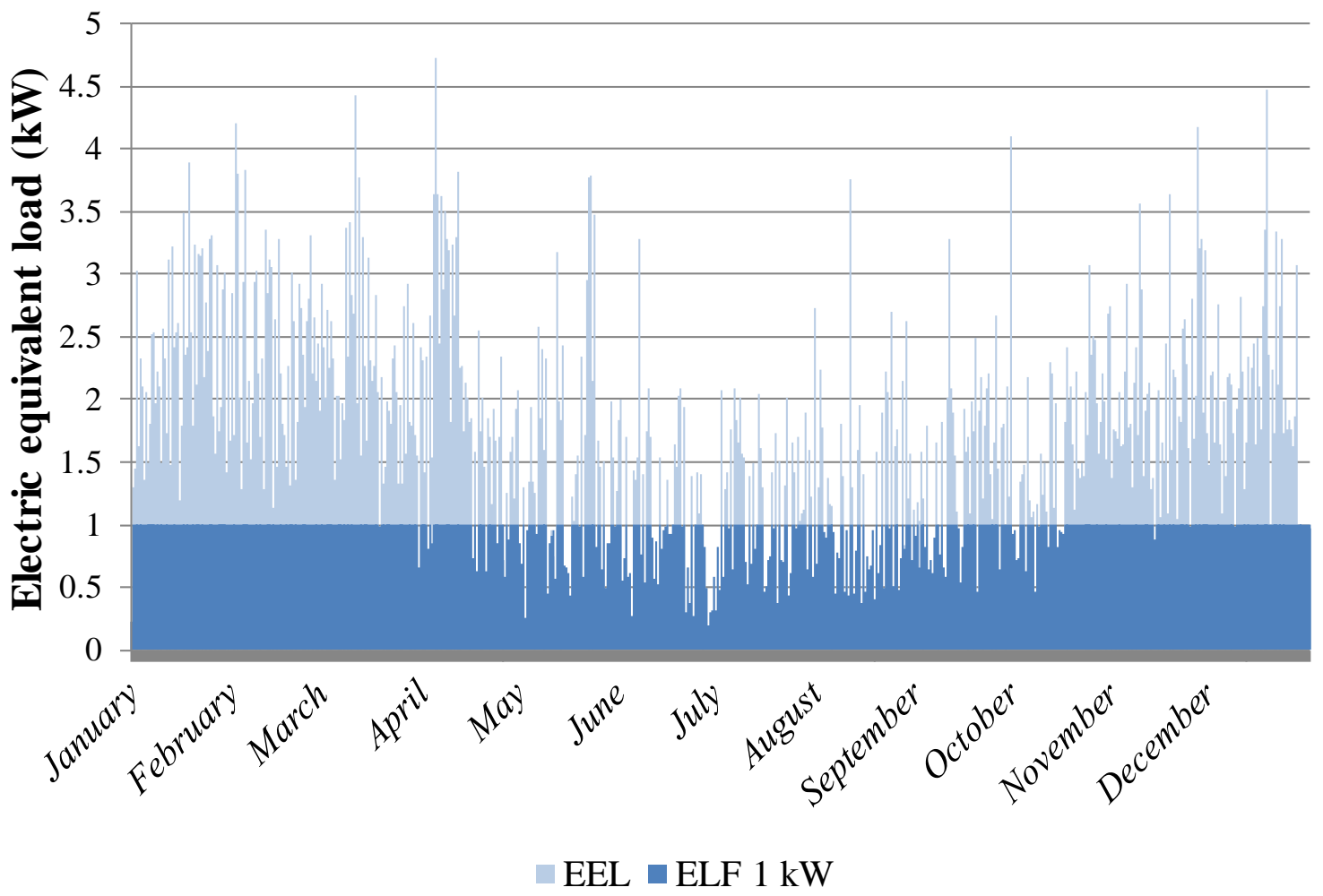

Figure 5. Electric equivalent load with ELF $1 \mathrm{~kW}$, annual overview. ELF $1 \mathrm{~kW}$ follows EEL until it is lower or equal to $1 \mathrm{~kW}$ (the darker color). 


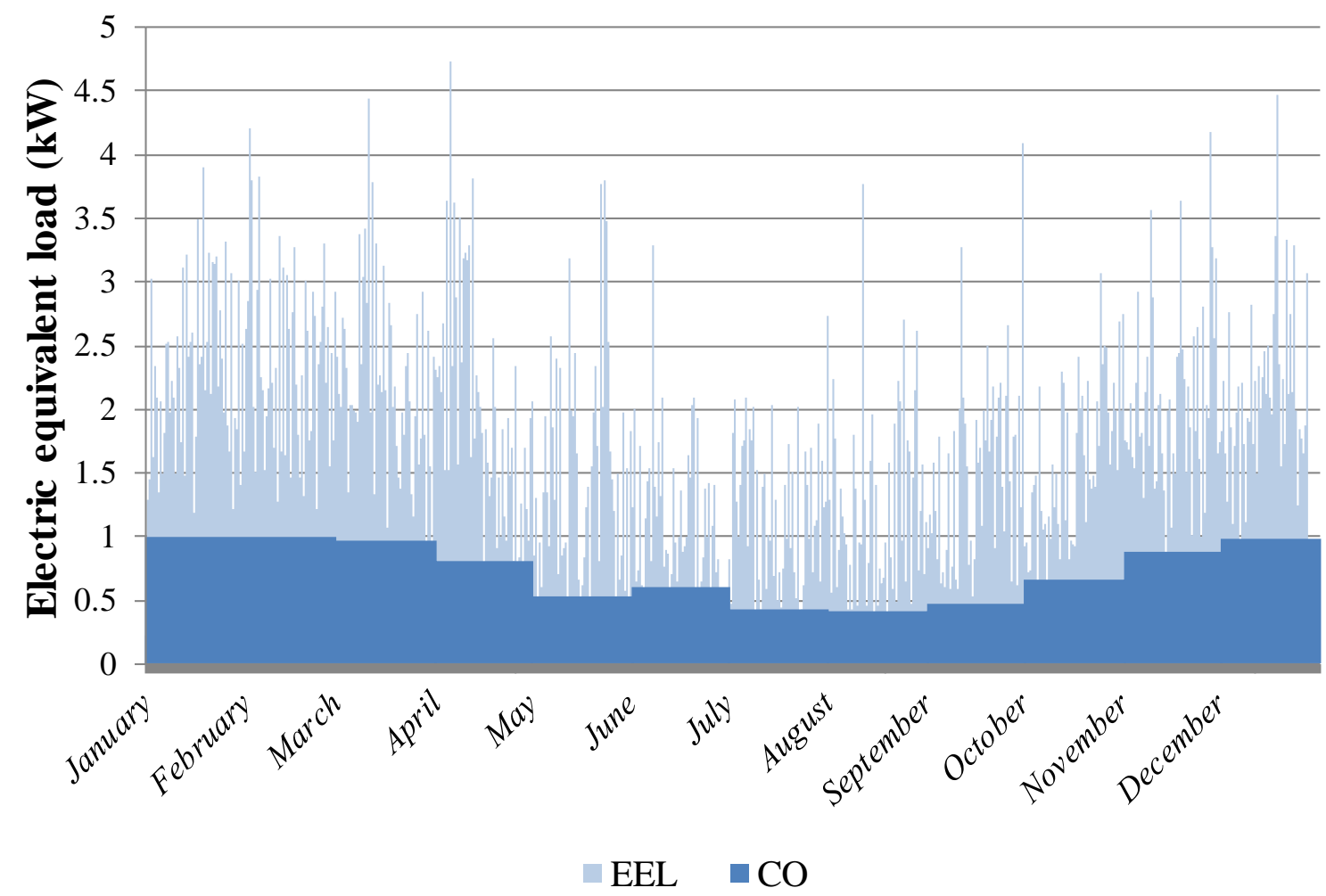

Figure 6. Electric equivalent load with continuous operation (CO) strategy, annual overview. CO follows a monthly average of EEL (the darker color).

\section{Cost Estimation}

To calculate the total cost of the plant, the investment cost for all of the components and the maintenance cost for heat pump and fuel cell shall be estimated first. These are explained below.

\subsection{Components' purchase cost}

The cost of the SOFC and related auxiliaries are analyzed first. In the future scenario and under serial production, the purchased cost of each SOFC stack $\left(\mathrm{C}_{\text {stack }}\right.$, in $\left.\$\right)$ can be estimated as [23],

$$
C_{\text {stack }}=\left(N_{\text {cell }} \pi D_{\text {cell }} L_{\text {cell }}\right)\left(2.96 T_{\text {cell }}-1907\right)
$$

where $N_{\text {cell }}$ is the number of the cells, $D_{\text {cell }}$ is the diameter of the cell, $L_{\text {cell }}$ is the length of the cell, and $T_{\text {cell }}$ is the operating temperature of the cell in kelvin. Assuming the number of cells to be 74 , the cell diameter to be $0.005 \mathrm{~m}$, the cell length to be $0.12 \mathrm{~m}$ and the operating temperature to be $1073 \mathrm{~K}$ then the uninstalled cost of each stack can be estimated.

The purchased cost of a counter flow plate heat exchanger $\left(\mathrm{C}_{\mathrm{HEX}}\right.$, in $\left.\$\right)$ is related to the area of the heat exchanger $\left(\mathrm{A}_{\mathrm{HEX}}\right.$, in $\left.\mathrm{m}^{2}\right)$ [23]. The area of the heat exchanger is related to the heat flow rate $(Q$, in $\mathrm{W}), \log$ mean temperature difference $\left(\triangle T_{L M T D}\right)$ and heat transfer coefficient $(U)$. For air-air heat exchangers (such as a fuel preheater), $U$ is estimated to be $35 \mathrm{~W} /\left(\mathrm{m}^{2} \mathrm{~K}\right)$, while for an air-water heat exchanger (heat recovery heat exchanger), its value is substantially higher and is estimated to be $133 \mathrm{~W} /\left(\mathrm{m}^{2} \mathrm{~K}\right)$. 


$$
\begin{aligned}
C_{H E X} & =130\left(\frac{A_{H E X}}{0.093}\right)^{0.78} \\
A_{H E X} & =\left(\frac{Q_{H E X}}{U \Delta T_{L M T D} 0.093}\right)^{0.78}
\end{aligned}
$$
[24]

The burner cost $\left(\mathrm{C}_{\text {burner}}\right.$, in \$) can be estimated from the mass flow of gases ( $\dot{m}$ in $\mathrm{kg} / \mathrm{s}$ ) as

$$
C_{\text {burner }}=42\left(\frac{\dot{m}}{0.028}\right)^{0.55}
$$

To invert the $\mathrm{DC}$ from the fuel cells into $\mathrm{AC}$, the inverter cost $\left(\mathrm{C}_{\mathrm{inv}}\right.$, in $\left.\$\right)$ will be related to the power of the cell ( $W_{\text {cell }}$, in W) [25].

$$
C_{\text {inv }}=10^{5}\left(\frac{W_{\text {cell }}}{500}\right)^{0.7}
$$

The compressor cost $\left(\mathrm{C}_{\text {comp }}\right.$, in $\left.\$\right)$ is estimated from the compression power $\left(W_{\text {compr }}\right.$, in $\left.\mathrm{kW}\right)$ $[25]$

$$
C_{\text {comp }}=91562\left(\frac{W_{\text {comp }}}{445}\right)^{0.67}
$$

The pre-reformer cost $\left(\mathrm{C}_{\mathrm{PR}}\right.$, in $\left.\$\right)$ is related to its characteristics area $\left(A_{P R}\right.$, in $\left.\mathrm{m}^{2}\right)$ and volume $\left(V_{P R}\right.$, in $\left.\mathrm{m}^{3}\right)$ as in [23],

$$
C_{P R}=130\left(\frac{A_{P R}}{0.093}\right)^{0.78}+3240 V_{P R}^{0.4}+21280 V_{P R}
$$

The cost of the desulfurizer $\left(\mathrm{C}_{\mathrm{des}}\right.$, in $\$$ ) is related to its production volume $\left(\mathrm{V}_{\text {prod }}\right.$, assuming it is between 100,000 and 500,000 units/years), its fuel mass flow ( $\dot{m}_{f u e l}$, in $\left.\mathrm{kg} / \mathrm{h}\right)$ and system power $\left(W_{s y s}\right.$, in $\left.\mathrm{kW}\right)[25]$,

$$
C_{\text {des }}=135.71 V_{\text {prod }}^{-0.1365} \dot{m}_{\text {fuel }}^{0.67} W_{\text {sys }}^{-1}
$$

These costs are the purchase equipment cost (PEC) without considering additional costs arising from direct and indirect costs, such as piping, instrumentation, and electrical equipment. These additional costs can be related to the PEC through a simple estimation discussed in [26]. Table 3 shows values for each direct or indirect cost considered here. The PEC of other components such as chillers and tanks are not included in the PEC considered in Table 3 because those costs are related to the technical datasheet, and it is assumed that direct and indirect costs are also considered in the respective data sheet.

Table 3. Direct and indirect costs of a system related to PEC 


\begin{tabular}{|l|l|}
\cline { 2 - 2 } \multicolumn{1}{c|}{} & PEC percentage \\
\hline \multicolumn{1}{|c|}{ Direct costs } & \\
\hline Purchase - Equipment installation & $45 \%$ PEC \\
\hline Piping & $35 \%$ PEC \\
\hline Instrumentation and controls & $20 \%$ PEC \\
\hline \multicolumn{1}{|c|}{ Indirect costs } & \\
\hline Engineering and supervisor & $8 \%$ PEC \\
\hline Construction costs and profit & $15 \%$ PEC \\
\hline
\end{tabular}

To convert from the US dollar [\$] to the Euro [€], the exchange rate used is $1.286 € / \$$. It shall be mentioned that the cost for the SOFC system is estimated to be $3195 €$ for $1 \mathrm{~kW}$ of nominal electric power, and $5067 €$ for $2 \mathrm{~kW} \mathrm{SOFC} \mathrm{system.} \mathrm{These} \mathrm{costs} \mathrm{are} \mathrm{in} \mathrm{agreement}$ with the present cost as well as target cost discussed in [27] and [28].

\subsection{GHSP and water tank purchase cost}

For the GSHP, an algebraic power regression is developed here to follow the technical datasheet of the heat pump and relates the cost of the heat pump $\left(C_{H P}\right.$, in $\left.€\right)$ to the nominal heating power of the GSHP $(P$, in $\mathrm{kW})$. The regression is found to be

$$
C_{H P}=4704.2 P^{0.2231}
$$

It is also necessary to estimate the cost of the ground heat exchanger coupled with the necessary drilling. A calculation method is thus proposed to calculate the heat absorbed by the GSHP $\left(\mathrm{P}_{\mathrm{ABS}}\right)$, which is related to the nominal heating power $\left(\mathrm{P}_{\text {nom }}\right)$ and to the electric consumption of the heat pump ( $\left.\mathrm{El}_{\text {cons }}\right)$. The electrical consumption is in turn related to the COP of the heat pump as,

$$
P_{A B S}=P_{n o m}-E l_{\text {cons }}=P_{\text {nom }}-\frac{P_{\text {nom }}}{C O P}=P_{\text {nom }}\left(1-\frac{1}{C O P}\right)
$$

The cost related to ground coupling and drilling is approximately $1 €$ of each $1 \mathrm{~W}$ of the absorbed heat $\left(\mathrm{P}_{\mathrm{ABS}}\right)$ from the ground. These criteria are chosen to simplify the cost estimation; otherwise, a cost estimation in $€ / \mathrm{m}$ of the ground coupling is usually used.

Similarly, for the water tank (storage), a power regression is developed to follow the technical datasheet of the tank and relate the cost estimation $\left(C_{\text {watertank }}\right.$, in $\left.€\right)$ to the capacity of the tank ( $\dot{m}_{\text {water }}$ in $\left.\mathrm{kg} / \mathrm{s}\right)$ as,

$$
C_{\text {water tank }}=12.333 \dot{m}_{\text {water }}^{0.813}
$$

\subsection{Maintenance cost}

The annual maintenance cost for the SOFC is proposed to be $23.23 € /$ stack ( $£ 20 /$ stack) according to [29], with an exchange rate of $£ 1=1.1617 €$. For the GSHP, the annual maintenance cost is $1 \%$ of the purchase cost according to [30]. The maintenance costs are affected by inflation, which is assumed to be $2 \%$ for all periods (this is the highest acceptable inflation for the ECB). Thus, one has 


$$
C_{\mathrm{t}}=C_{0}\left(1+i_{\text {inf }}\right)^{t-1}
$$

where $C_{t}$ is the cost at period $t, i_{\text {inf }}$ is the inflation rate, $C_{0}$ is the cost at the end of the first year and $t$ is the time period. In the equation, $t-1$ is used instead of $t$ because the cost of the first year is given, and this cost is assumed to be constant until the next year.

\subsection{Energy cost}

To calculate the operating cost of the system, it is essential to know the cost of electricity and fuel in Denmark. Data referred to in the second half-year of 2012 was chosen as 0.2972 $€ / \mathrm{kWh}$ for electricity [31] and $0.1083 € / \mathrm{kWh}$ for natural gas [32] (including tax). Energy prices of gas and electricity are not constant and vary every year. Therefore, it is necessary to define an index, which accounts for the increase of both electricity and gas prices per year. The average yearly increase in the price of electricity and gas has been assumed to be $3.75 \%$ and 3.84\%, respectively, which corresponds to recent years (2009-2013) in Denmark [31], [32]. Thus, one has

$$
C_{\mathrm{t}}=C_{0}\left(1+i_{c}\right)^{t-1}
$$

where $C_{t}$ is the cost at period $t, i_{c}$ is the increasing index for the price, $C_{0}$ is the cost at the end of the first year and $t$ is the period. In the equation, $t-1$ is used instead of $t$ because the cost of the first year is given, and it is assumed to be constant until the next year.

\section{Thermodynamic Analysis}

To analyze the system, thermodynamic benchmarks are used:

- overall efficiency of the fuel cell;

- primary energy saving (PES) of the entire system (fuel cell and heat pump);

- production and consumption of different types of energy (electricity and heat) divided for each component of the system.

To provide the same quantities of energy, PES is related to the fuel consumption of the fuel cell, energy consumption of the system (electricity and heat) and also to the efficiency that a traditional system with separated production of heat and electricity has. PES is defined according to the study of a trigeneration system in [22] as

$$
\% P E S=1-\frac{F_{\text {SOFC }}+\frac{E_{\text {Grid }}}{\eta_{\text {el }}}}{\frac{H_{\text {Demand }}}{\eta_{\text {boiler }}}+\frac{E_{\text {Demand }}}{\eta_{e l}}}
$$

$\mathrm{F}_{S O F C}$ is the fuel consumption of the system, $\mathrm{E}_{G R I D}$ is the net electricity consumption from the grid (if the system has an exchange of electricity with the grid, then the difference between these two variables is considered), $\mathrm{H}_{D E M A N D}$ is the heat demand from the user, and $\mathrm{E}_{D E M A N D}$ is the electricity demand of the user. $\eta_{\text {boiler }}$ is the efficiency of a traditional gas boiler used in a traditional system that covers heating and DHW demands. $\eta_{e l}$ is the efficiency of an electric energy consumer from the grid, considering both generation with a traditional power plant and grid efficiency. A traditional system covers the electricity demand only from the grid, while the innovative system proposed consumes electricity from the grid only when the SOFC produces less electricity than the demand from the user and/or heat pump. Table 1 shows the values that are considered here.

The overall efficiency of the fuel cell $\left(\eta_{S O F C}\right)$ can be defined as

$$
\eta_{\text {SOFC }}=\frac{E+H_{S O F C}}{F_{S O F C}}
$$


where $E$ is the net electricity produced by the SOFC (considering auxiliaries consumption and inverter efficiency), $H_{S O F C}$ is the heat available and $F_{S O F C}$ is the fuel consumption.

Fig. 7 shows the PES and overall efficiency of the fuel cell for all of the different strategies discussed above (ELF $2 \mathrm{~kW}$, ELF $1 \mathrm{~kW}$ and ELF CO). As seen, the overall efficiency is higher than $90 \%$ for all of the cases considered, while the PES is higher than $45 \%$.

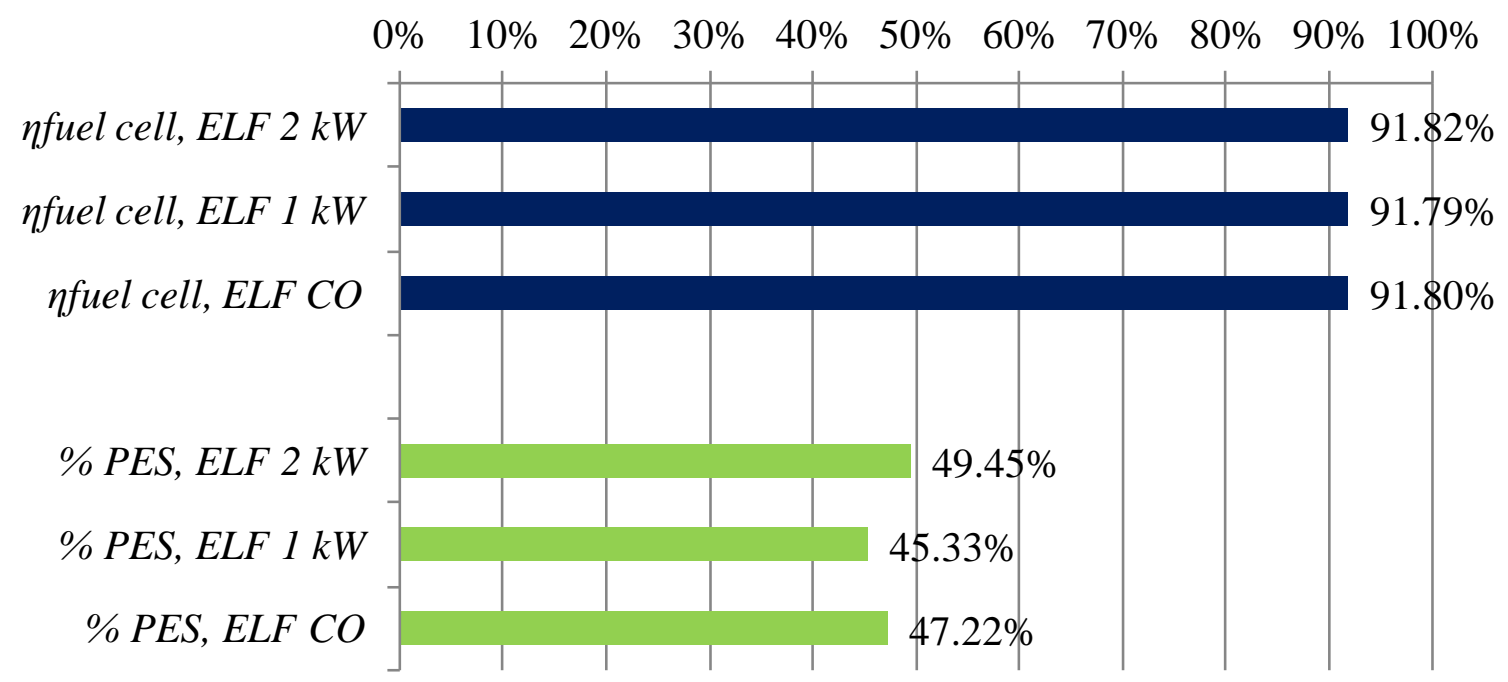

Figure 7. Fuel cell efficiency and \%PES for all of the strategies.

\subsection{ELF $2 \mathrm{~kW}$}

The ELF 2-kW case has the highest value of PES (49.45\%) because of the size of the SOFC. A larger fuel cell is able to cover more electricity demand and GSHP consumption. It is also able to cover more waste heat so that the heat required by the heat pump is lower. Under this operation strategy, the electricity required to the grid is low. Fig. 8 shows that only $212 \mathrm{kWh}$ of electricity is consumed from the grid during the periods of high request, and 198 $\mathrm{kWh}$ is provided to the grid when the consumption is lower than the request. 


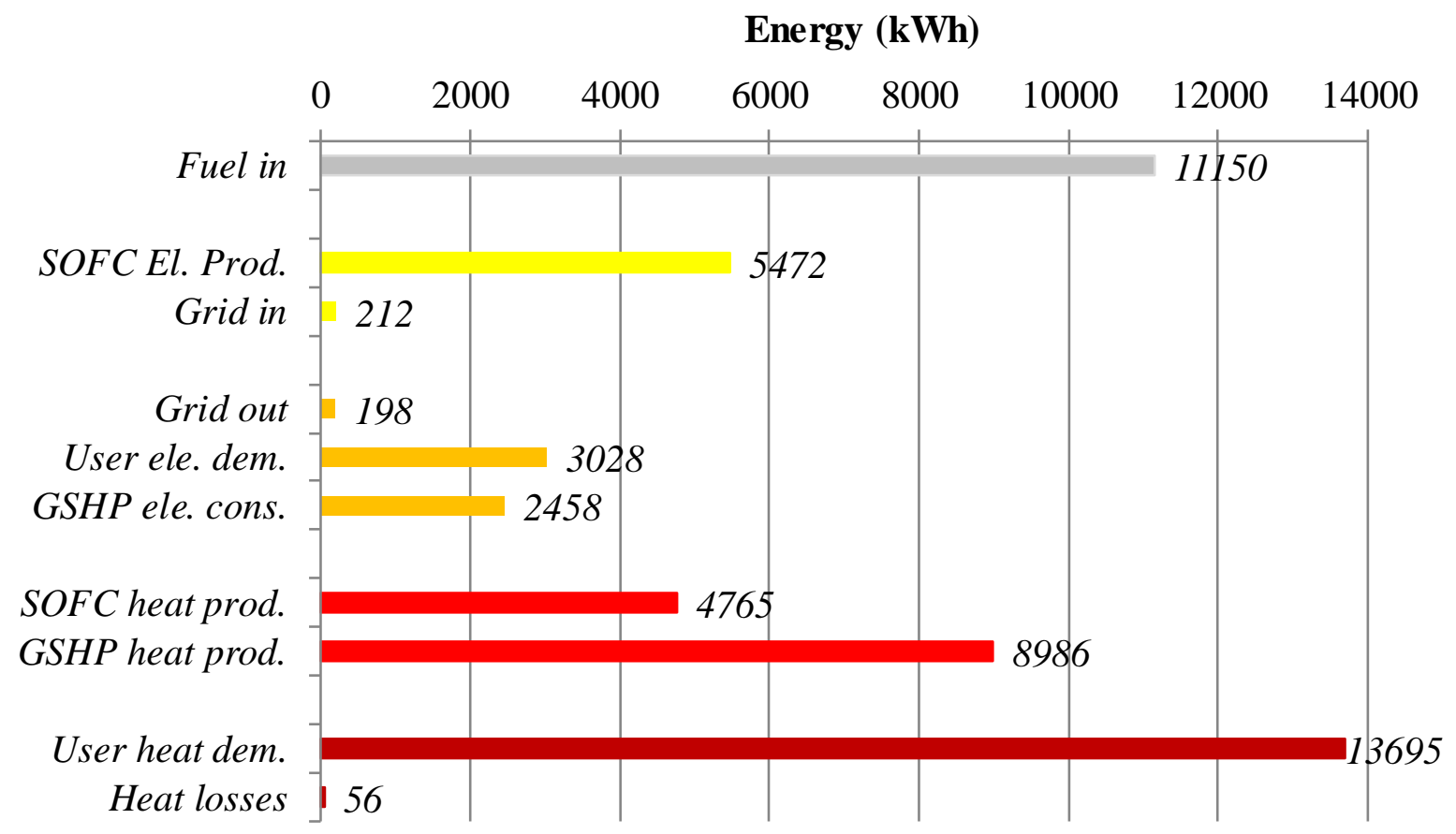

Figure 8. Energy flux for the ELF 2-kW operation strategy.

\subsection{ELF $1 \mathrm{~kW}$}

The system working under ELF $1 \mathrm{~kW}$ has a smaller fuel cell (nominal power of $1 \mathrm{~kW}$ instead of $2 \mathrm{~kW}$ ); therefore, both the electricity and heat demand covered by the fuel cell is lower compared with the previous case. Consequently, the PES decreases to $45.33 \%$. Fig. 9 shows that the heat recovery is $3854 \mathrm{kWh}(28.15 \%$ of the user heat demand, $13695 \mathrm{kWh})$ while under ELF $2 \mathrm{~kW}$, the heat recovery is $4765 \mathrm{kWh}$ (34.8\% of the user heat demand). The electricity consumption from the grid is thus higher because of lower electricity production (4340 kWh in ELF $1 \mathrm{~kW}$ instead of $5472 \mathrm{kWh}$ in ELF $2 \mathrm{~kW}$ ) and because the heat pump consumes more electricity than the ELF $2-\mathrm{kW}$ case, (it is related to the lower waste heat available). Higher electricity consumptions from the grid explain why the PES decreases in this case compared to the previous case. 


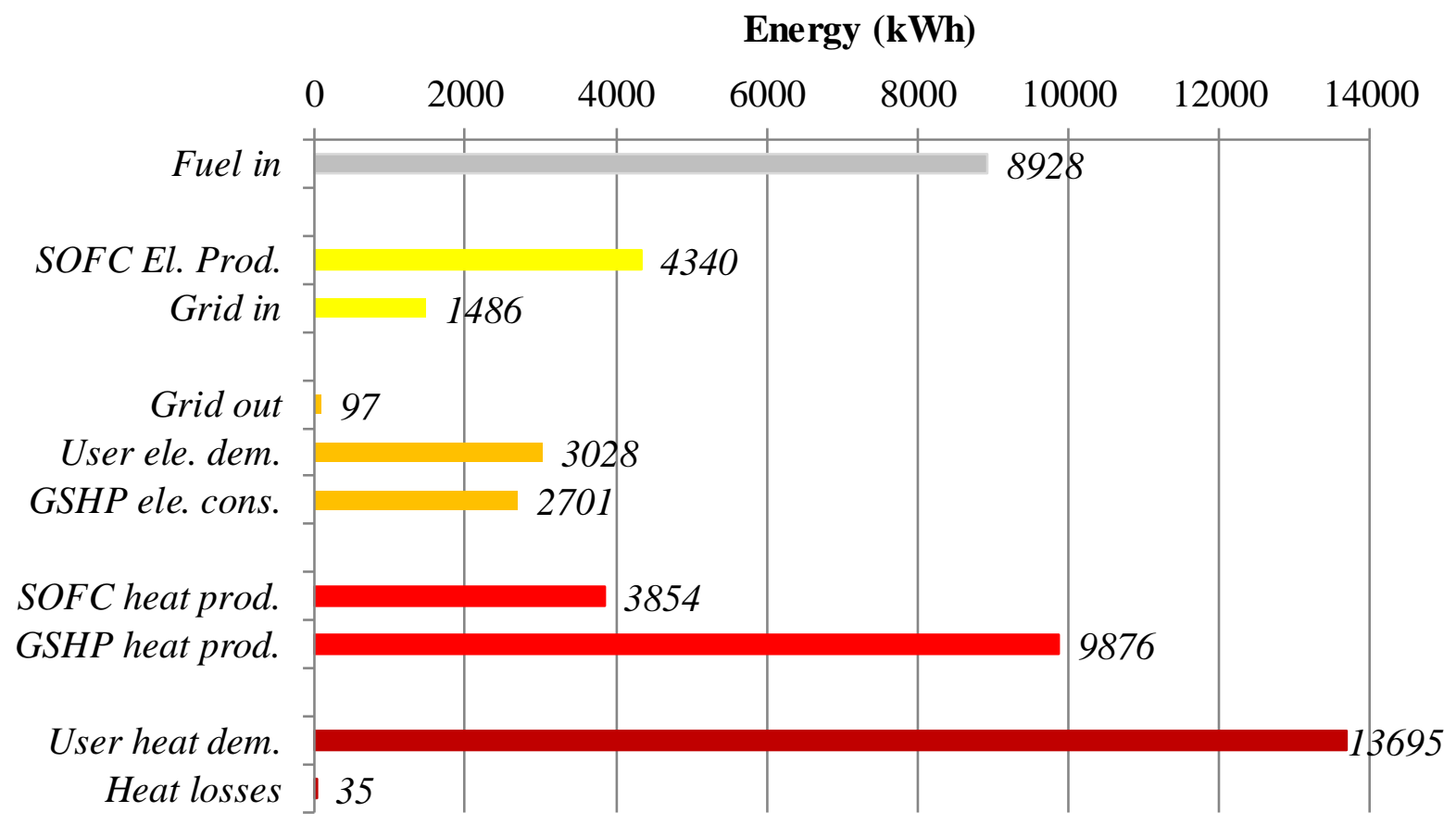

Figure 9. Energy flux for the ELF 1-kW operation strategy.

\subsection{ELF CO}

The system working under the ELF CO strategy has a fuel cell with constant electricity and heat production during the day. This constant value is the average of the electricity required during the considered period. Fig. 10 displays this operation strategy has a high exchange of electricity with the grid. Electricity from the grid of $1802 \mathrm{kWh}$ is consumed when the consumption is higher than the demand, while $2025 \mathrm{kWh}$ is given to the grid when the consumption is lower than the demand. This is related to mismatching between the production and consumption of electricity. Because of this mismatching, the heat losses are the highest of all of the cases analyzed here $(199 \mathrm{kWh})$. 


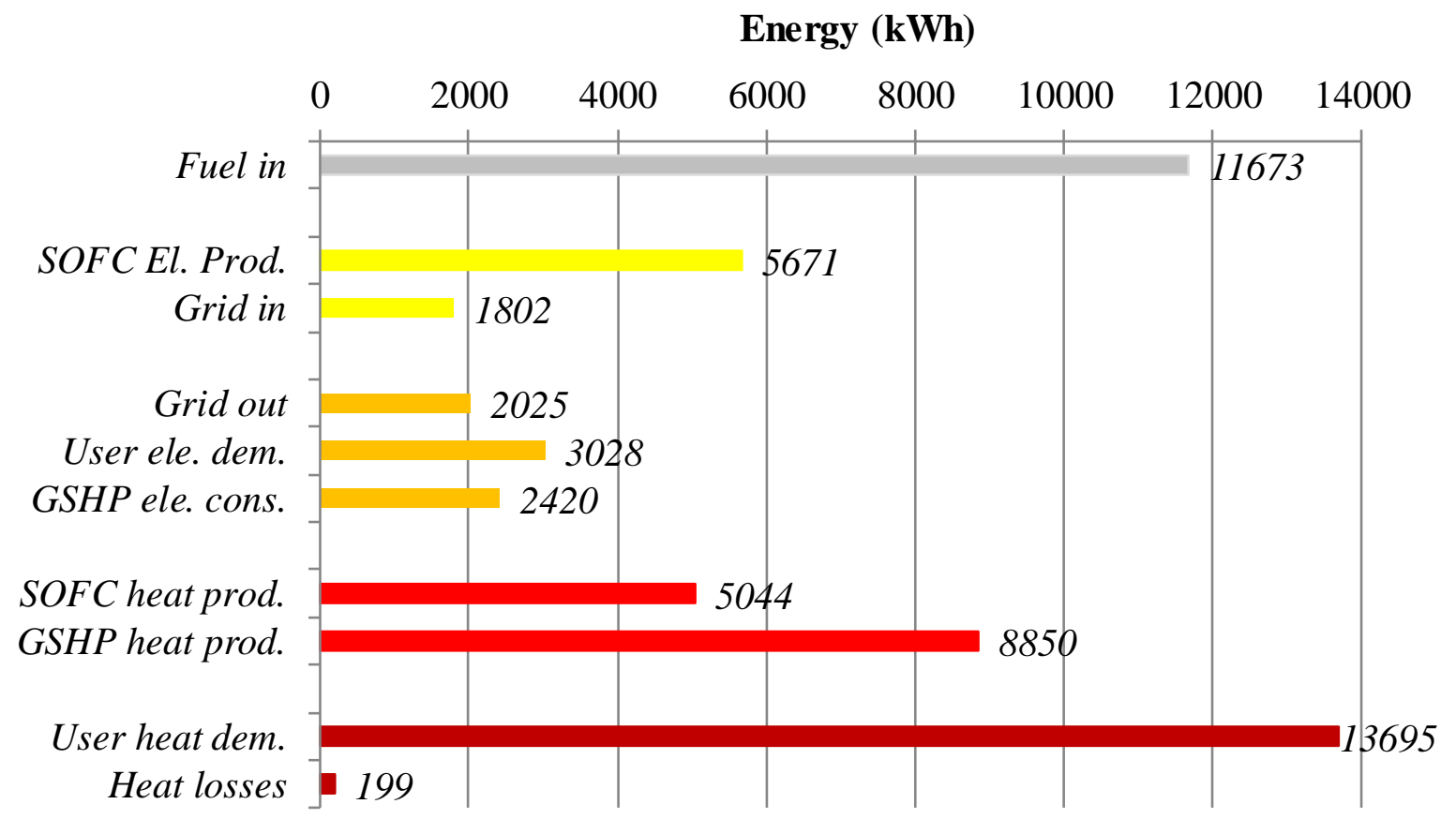

Figure 10. Energy flux for the ELF CO strategy.

\section{Economic Analysis}

The primary aim of the proposed system is to save energy because higher overall efficiency means savings on electricity consumption and/or fuel by lowering the annual operating cost. Each system is analyzed using the following economical benchmarks:

- Net Present Value (NPV) and Pay Back $(P B)$ time to evaluate the revenue and the duration of the investment. The life expectation of the system is considered to be 20 years, and the interest rate is taken as $i=3 \%$;

- The Sensitivity Analysis evaluates which variation of variables (energy costs, fuel cell or other component prices) has a higher influence on the convenience of the investment. It is a useful tool not only for the uncertainty on the prices and the costs in the future but also for understanding which parameters are more important for consideration. The sensitivity analysis is chosen to vary between $-50 \%$ and $100 \%$ of the component purchased cost and between $1 \%$ and $10 \%$ of the average increasing index of energy costs (both gas and electricity) to see how they affect the NPV value.

No subsidy is considered; thus, the ELF CO strategy is not analyzed here because of the high exchange of electricity between the grid and system. It would be necessary to consider the net metering value, that is, a type of subsidy for power generation.

\subsection{ELF 2 kW}

The system under the ELF 2-kW operation strategy has an NPV of $€ 7300$ with a PB time of 15 years (Fig. 11). Fig. 12 indicates that the system has a higher sensitivity for the purchase cost of the heat pump. Additionally, by increasing the SOFC purchase cost by $100 \%$, the NPV will still be positive. Uncertainty on the SOFC cost is high because the purchasing cost is an estimation for the future scenario when production volume is sufficiently high. This analysis confirms that there are margins on the higher price of the fuel cell. The gas and electricity prices have different weights on the profit of a system, and it would be interesting to see their effect on the system analyzed here. Fig. 13 displays that if the annual increasing cost rate is 
lower than $4 \%$, the NPV is more sensitive to the gas price versus the electricity price. If the annual rate is higher than $4 \%$, then the NPV is more sensitive to the electricity price.

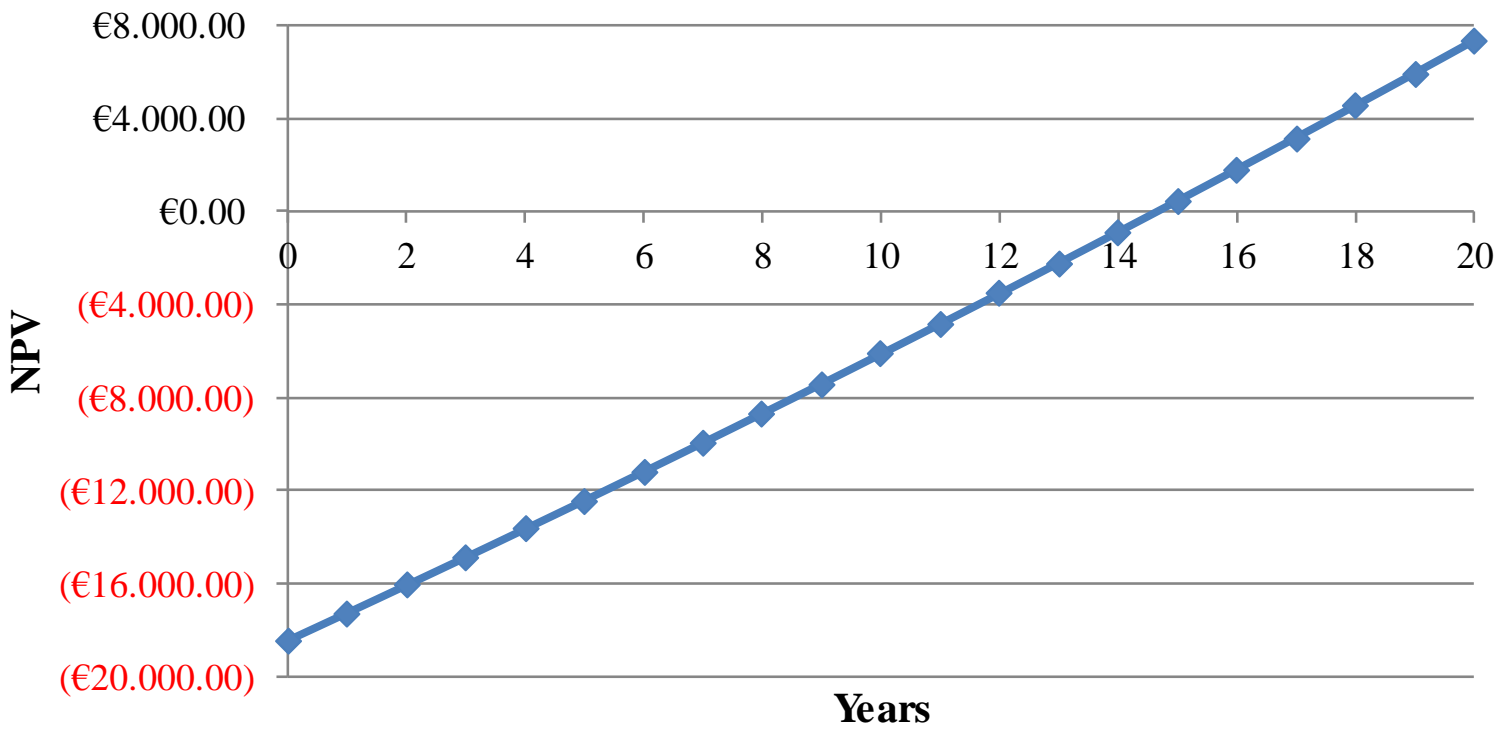

Figure 11. NPV with ELF $2 \mathrm{~kW}$.

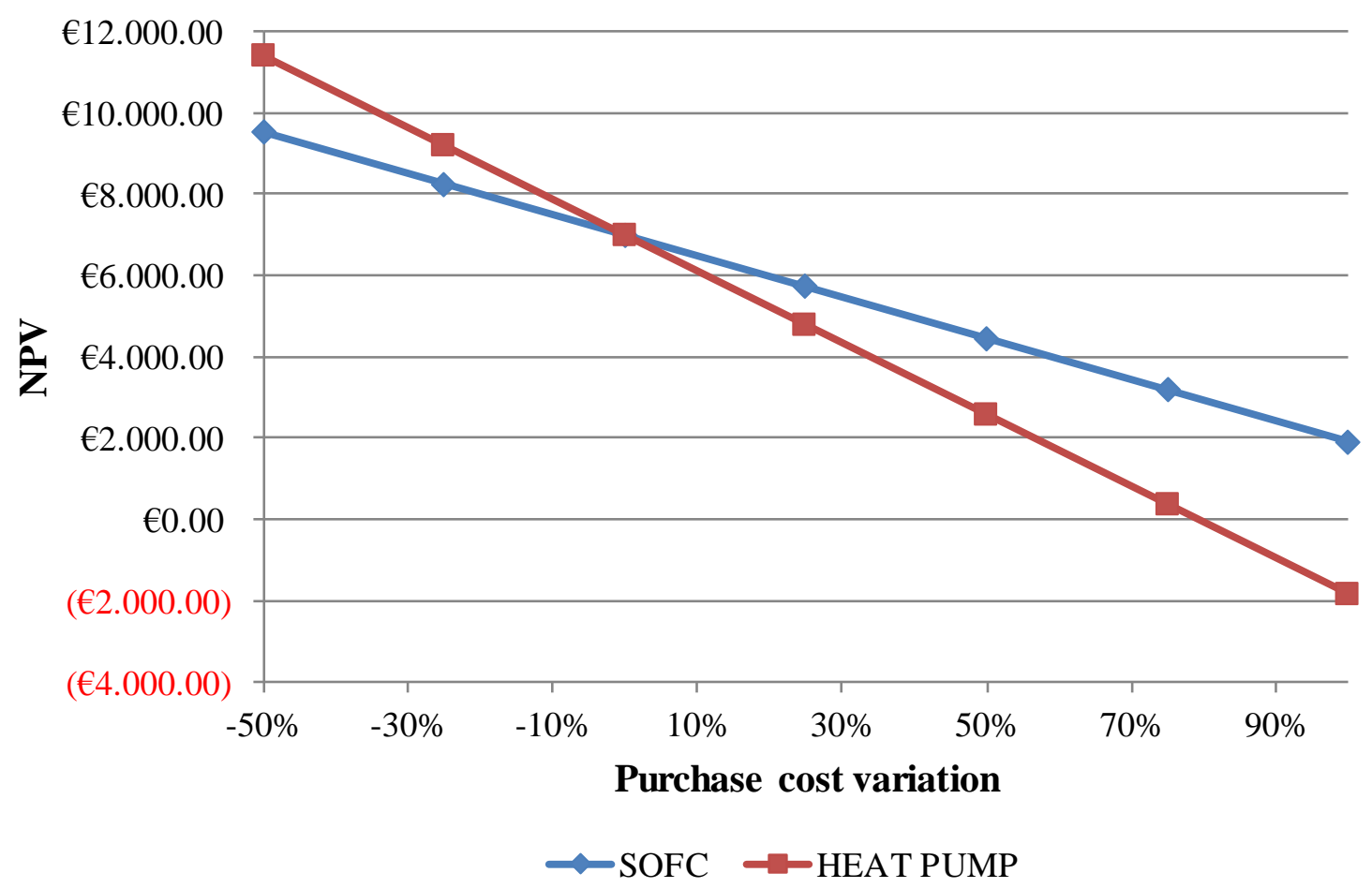

Figure 12. Sensitivity analysis on the purchase cost with ELF $2 \mathrm{~kW}$. 


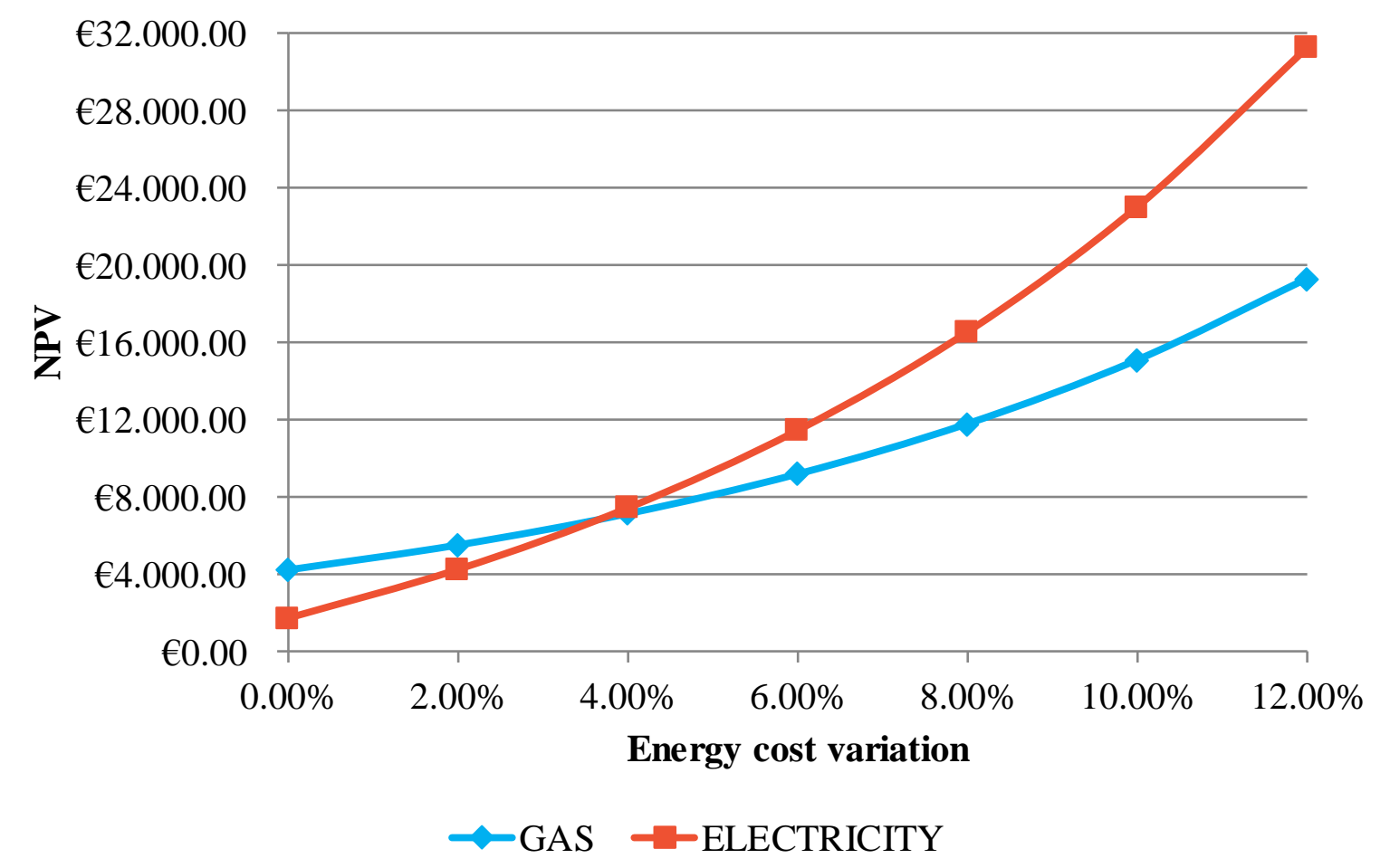

Figure 13. Sensitivity analysis on the energy cost with ELF $2 \mathrm{~kW}$.

\subsection{ELF $1 \mathrm{~kW}$}

The system under the ELF 1-kW operation strategy has an NPV of $€ 4800$ with a PB time of 16 years (Fig. 14). The purchase cost of the fuel cell is lower in this case because of lower nominal power, and as the result, the NPV is less sensitive on the SOFC purchase cost. By increasing the fuel cell purchase cost by $100 \%$, the NPV will still be positive as shown in Fig. 15. For electricity and gas prices, Fig. 16 shows that the system is more sensitive when increasing the gas price versus the electricity price. The results are quite different compared to the previous operation strategy discussed above (c.f. Fig. 12), and this can be explained by the different consumption of fuel and electricity from the grid under these operating strategies (c.f. Fig. 8 and Fig. 9).

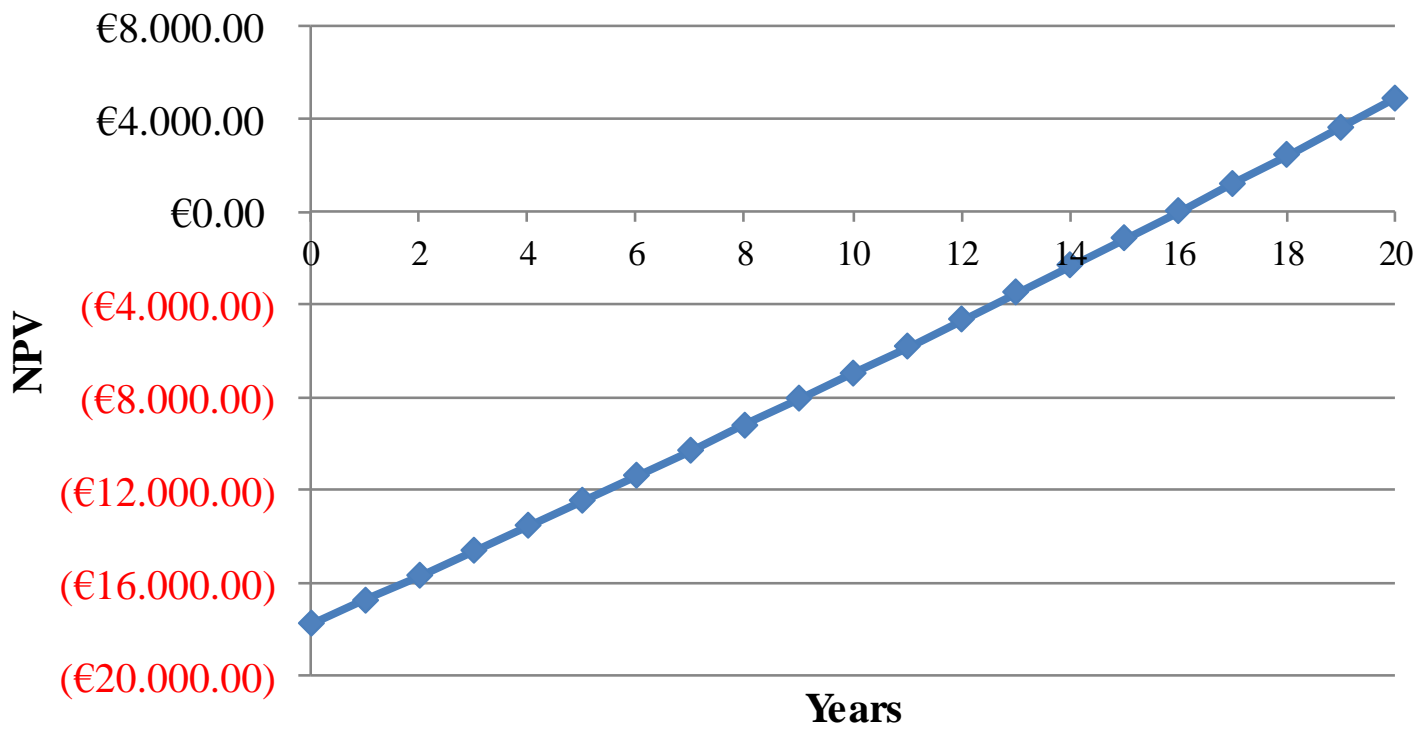

Figure 14. NPV with ELF $1 \mathrm{~kW}$. 


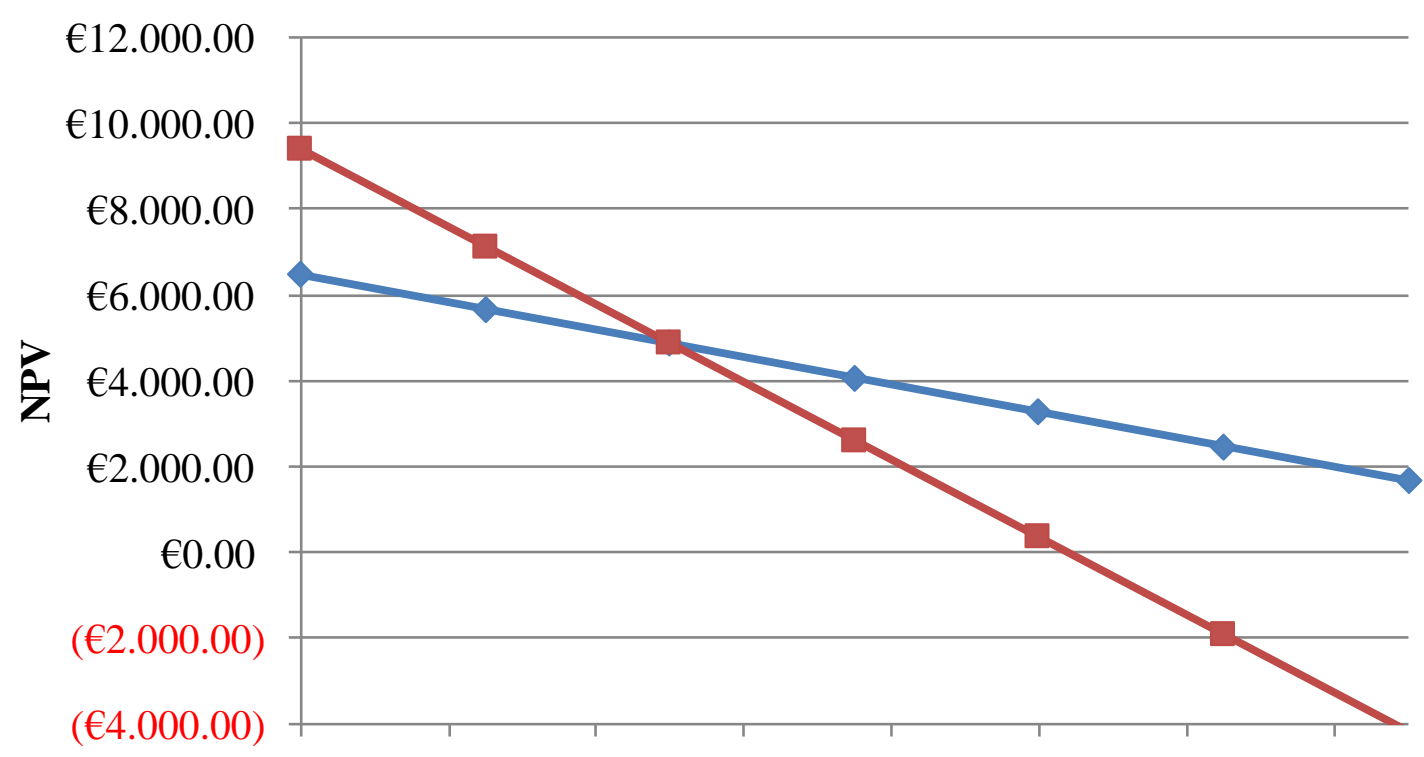

$-50.00 \%-30.00 \%-10.00 \% \quad 10.00 \% \quad 30.00 \% \quad 50.00 \% \quad 70.00 \% \quad 90.00 \%$

Purchase cost variation

$\sim$ SOFC $\rightarrow$ HEAT PUMP

Figure 15. Sensitivity analysis on the purchase cost with ELF $1 \mathrm{~kW}$.

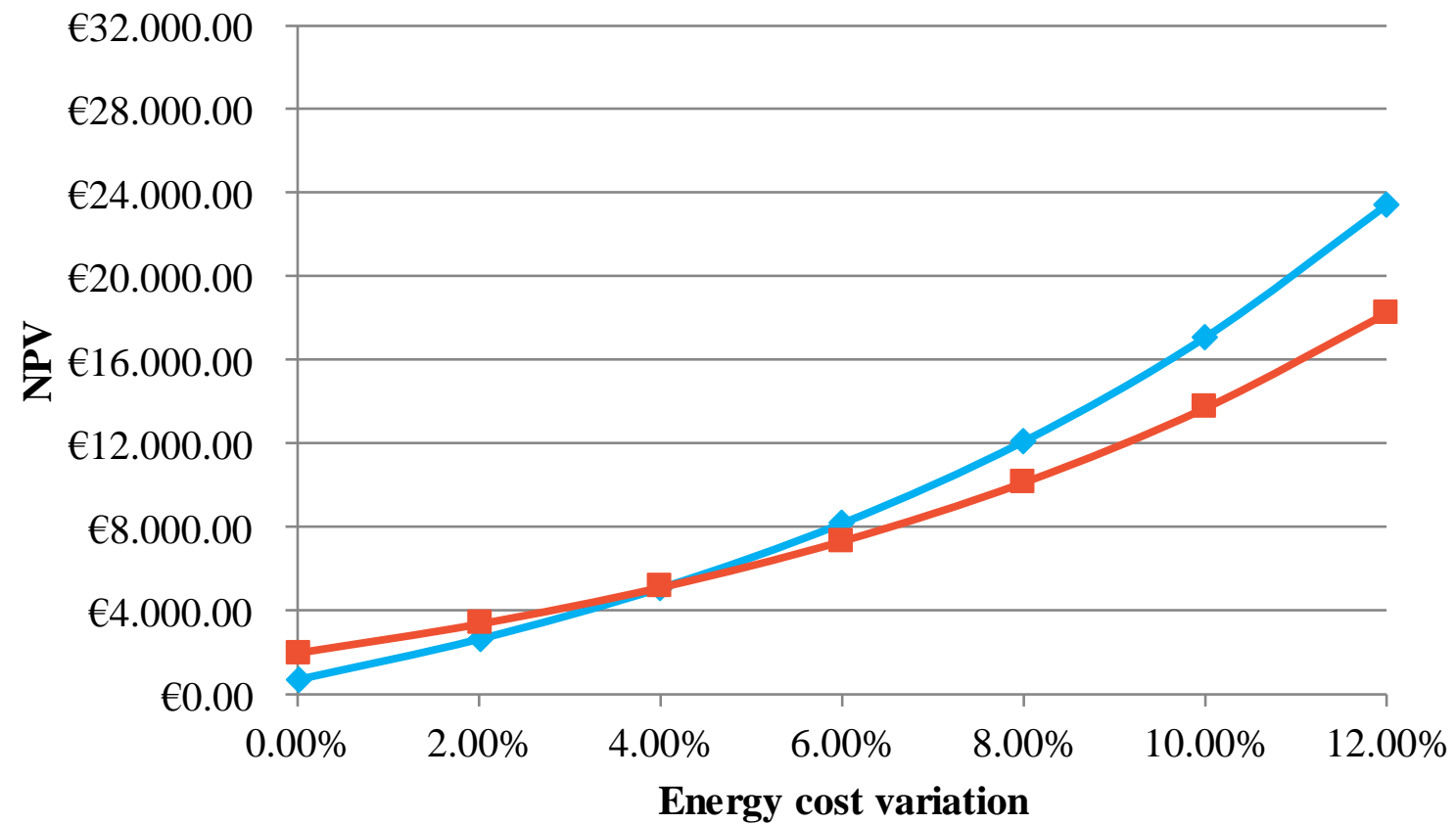

$\leadsto$ GAS $\rightarrow-$ ELECTRICITY

Figure 16. Sensitivity analysis on the energy cost with ELF $1 \mathrm{~kW}$.

\section{Conclusions}

An innovative cogeneration system based on the SOFC and GSHP is proposed for a resort located in a northern European country (Denmark). Additionally, an innovative parameter 
(electric equivalent load) is used to accomplish both the electricity and heat demand of the user and also define three different operation strategies, including ELF $2 \mathrm{~kW}$, ELF $1 \mathrm{~kW}$ and ELF CO. For all cases, it is found that there is a high primary energy saving and that the system is profitable, even though the payback time is high (15 to 16 years). The uncertainty of the energy price and inflation rate is high during a long period.

The ELF 2-kW operation strategy confirms that the system proposed could be independent from the grid when the system is allowed to exchange electricity with the grid and when there is mismatching between The electricity production and request. Eventually, other electrical storage could be interesting to study to make the system stand-alone and independent to the grid.

The ELF 1-kW operation strategy has the highest value of NPV, even if the payback time is the same as the ELF $2 \mathrm{~kW}$ strategy. Both the ELF $2 \mathrm{~kW}$ and ELF $1 \mathrm{~kW}$ strategies requires a small water tank because they have the capacity of following the heat demand from the user.

The ELF CO operation strategy also gives high primary energy saving even though the fuel cell works at constant load and does not follow the user demand. In this strategy, high thermal stress because of frequent start and shutdown is avoided. Mismatching between the electricity production and consumption is high, and the economic analysis of this strategy could only be performed once the net metering subsidy is available.

The SOFC stack purchase cost is not the highest weight of profitability for the system proposed here, and this is in fact an advantage because the fuel cell cost is estimated under the assumption of high volume production and therefore allows margins for the higher purchase cost of the stacks.

Gas and electricity have a different weight on the profitability of the system and depend on the operation strategy and annual increase in energy cost.

High thermodynamic performances and a positive NPV prove that this cogeneration system could be a possible solution for household application both for energy saving and distributed generation because the users will be able to cover their own electricity consumption.

\section{References}

[1] Sanchez D, Chacartegui R, Torres M, Sanchez T. Stirling based fuel cell hybrid systems: an alternative for molten carbonate fuel cells. Power Sources 2008;192:84-93.

[2] Rokni M. Thermodynamic analysis of SOFC (solid oxide fuel cell) - Stirling hybrid plants using alternative fuels. Energy 2013;61:87-97.

[3] Lee KH, Strand RK. SOFC cogeneration system for building applications, part 2: System configuration and operating condition design. Renewable Energy 2009; 34(12):2839-46.

[4] Calise F, Dentice d'Accadia M, Palombo A, Vanoli L. Simulation and exergy analysis of a hybrid solid oxide fuel cell (SOFC)-Gas turbine system. Energy 2006;31:3278-99.

[5] EG\&G and G Technical Services Inc, Fuel Cell Handbook, edition 7, U.S. Departement of Energy, Office of Fossil Energy, National Energy Technology Laboratory, 2004.

[6] Riensche E, Achenbach E, Froning D, Haines MR, Heidug WK, Lokurlu A and Adrian S. Clean combined-cycle SOFC power plant-cell modeling and process analysis. Power Sources 2000;86(1-2):404-410.

[7] Bellomare F, Rokni M. Integration of a Municipal Solid Waste Gasification with Solid Oxide Fuel Cell and Gas Turbine. Renewable Energy 2013;55:490-500.

[8] Rokni, M. Thermodynamic Analysis of an Integrated Solid Oxide Fuel Cell Cycle with a Rankine Cycle, Energy Conversion and Management 2010;51(12):2724-32. 
[9] Rokni M. Plant characteristics of an integrated solid oxide fuel cell and a steam cycle. Energy 2010;35:4691-99.

[10] Pierobon L, Rokni M, Larsen U, Haglind F. Thermodynamic analysis of an integrated gasification solid oxide fuel cell plant combined with an organic Rankine cycle. Renewable Energy 2013;38:226-234.

[11] Rokni M, Biomass gasification integrated with a solid oxide fuel cell and Stirling engine, Energy (2014), in press, http://dx.doi.org/10.1016/j.energy.2014.01.078.

[12] Cooper SJG, Hammond GP, McManus MC, Ramallo-Gonzlez A, Rogers JG. Effect of operating conditions on performance of domestic heating systems with heat pumps and fuel cell micro-cogeneration. Energy and Buildings 2014;70:52-60.

[13] Bompard E, Napoli R, Wan B, Orsello G. Economics evaluation of a 5kW SOFC power system for residential use. Hydrogen Energy 2008;33:3243-47.

[14] Farhad S, Hamdullahpur F, Yoo Y. Performance evaluation of different configurations of biogas-fuelled SOFC micro-CHP systems for residential applications. Hydrogen Energy 2010;35:3758-68.

[15] Liso V, Brandon N, Zhao Y, Nielsen MP, Koer SK. Analysis of the impact of heat-topower ratio for a SOFC-based mCHP system for residential application under different climate regions in Europe. Hydrogen Energy 2011;36: 13715-26.

[16] Lamas J, Shimizu H, Matsumura E, Senda J. Fuel consumption analysis of a residential cogeneration system using a solid oxide fuel cell with regulation of heat to power ratio. Hydrogen Energy 2013;38:16338-43.

[17] UNI/TS 11300-4:2010 "Renewable energy and other generation systems for space heating and domestic hot water production" (Italian), Ente Nazionale Italiano di Unificazione.

[18] EN 14825:2008. Air conditioners, liquid chilling packages and heat pumps, with electrically driven compressors, for space heating and cooling - Testing and rating at part load conditions and calculation of seasonal performance. European Committee for Standardisation.

[19] Busato F, Lazzarin R, Noro M. Energy and economic analysis of different heat pump systems for space heating. Low-Carbon Technologies 2012;7:104-112.

[20] Annex 42. The Simulation of Building-Integrated Fuel Cell and Other Cogeneration Systems (COGEN-SIM). IEA Energy Conservation in Buildings \& Community Systems. Online available: http://www.ecbcs.org/annexes/annex42.htm, Feb. 2014.

[21] "Typisk varmeforbrug", Varde Forsyning A/S. In Danish. Online available: http://vardeforsyning.dk/Varme/Typisk-varmeforbrug.aspx, Feb. 2014.

[22] Kavvadias KC, Tosios AP, Maroulis ZB. Design of a combined heating, cooling and power system: Sizing, operation strategy selection and parametric analysis. Energy Conversion and Management 2010; 51(4):833-845.

[23] Arsalis A. Thermo economic modelling and parametric study of hybrid SOFC-gas turbine-steam turbine power plants ranging from 1.5 to 10 MWe. Power Sources 2008; 181(2):313-326.

[24] Zhang J. and Yamanis J. Techno-economical feasibility of highly efficient costeffective thermoelectric-SOFC hybrid power generation system. United Technologies Research Centre 2007:DE-FC26-05NT42626. http://www.osti.gov/scitech/biblio/967360.

[25] Braun. R. Techno-economic optimal design of solid oxide fuel cell system for microcombined heat and power application in U.S. ASME Fuel Cell Science and Technology 2010; 7: 031018-1.

[26] Bejan A, Tsatsaronis G, Moran M. Thermal design and optimization. New York: John Wiley and Sons Inc. 1996. 
[27] Otomo J, Oishi J, Mitsumori T, Iwasaki H, Yamada K. Evaluation of cost reduction potential for $1 \mathrm{~kW}$ class SOFC stack production: Implications for SOFC technology scenario. Hydrogen Energy 2013;38:14337-47.

[28] Staffell I, Green R. The cost of domestic fuel cell micro-CHP systems. Hydrogen Energy 2013;38:1088-1102.

[29] Hawkes AD, Aguiar P, Hernandez-Aramburo CA, Leach MA, Brandon NP, Green TC, Adjiman CS. Techno-economic modelling of a solid oxide fuel cell stack for micro combined heat and power. Power Sources 2006;156(2):321-333.

[30] Dickinson J, Jackson T, Matthews M, Cripps A. The economic and environmental optimisation of integrating ground source energy system into building. Energy 2009;34(12): 2215-22.

[31] "Electricity prices for domestic consumers, from 2007 onwards - bi-annual data (last update: 22-05-2013)”. Eurostat (2013), accessed 15 July 2013.

http://appsso.eurostat.ec.europa.eu/nui/show.do?dataset=nrg_pc 204\&lang=en

[32] "Gas prices for domestic consumers, from 2007 onwards - bi-annual data (last update: 22-05-2013)" Eurostat (2013), accessed 15 July 2013.

http://appsso.eurostat.ec.europa.eu/nui/show.do?dataset=nrg_pc_202\&lang=en 